IZA DP No. 964

The Shift to Services:

\title{
A Review of the Literature
}

Ronald Schettkat

Lara Yocarini

December 2003 


\title{
The Shift to Services: A Review of the Literature
}

\author{
Ronald Schettkat \\ Russell Sage Foundation, \\ Utrecht University and IZA Bonn
}

Lara Yocarini

Utrecht University

\section{Discussion Paper No. 964 \\ December 2003}

\author{
IZA \\ P.O. Box 7240 \\ D-53072 Bonn \\ Germany \\ Tel.: +49-228-3894-0 \\ Fax: +49-228-3894-210 \\ Email: iza@iza.org
}

This Discussion Paper is issued within the framework of IZA's research area The Future of Labor. Any opinions expressed here are those of the author(s) and not those of the institute. Research disseminated by IZA may include views on policy, but the institute itself takes no institutional policy positions.

The Institute for the Study of Labor (IZA) in Bonn is a local and virtual international research center and a place of communication between science, politics and business. IZA is an independent, nonprofit limited liability company (Gesellschaft mit beschränkter Haftung) supported by Deutsche Post World Net. The center is associated with the University of Bonn and offers a stimulating research environment through its research networks, research support, and visitors and doctoral programs. IZA engages in (i) original and internationally competitive research in all fields of labor economics, (ii) development of policy concepts, and (iii) dissemination of research results and concepts to the interested public. The current research program deals with (1) mobility and flexibility of labor, (2) internationalization of labor markets, (3) welfare state and labor market, (4) labor markets in transition countries, (5) the future of labor, (6) evaluation of labor market policies and projects and (7) general labor economics.

IZA Discussion Papers often represent preliminary work and are circulated to encourage discussion. Citation of such a paper should account for its provisional character. A revised version may be available on the IZA website (www.iza.org) or directly from the author. 
IZA Discussion Paper No. 964

December 2003

\section{ABSTRACT}

\section{The Shift to Services: A Review of the Literature}

The present paper provides an overview of literature on the shift to services. It follows the three dimensions of structural change - final demand, the inter-industry division of labor and inter-industry productivity differences. It first looks at the 'classics', however (Fisher (1935), Clark (1940), Fourastié (1949), Baumol (1967, 2001), and Fuchs (1968)). Next, it treats studies analyzing differences in service-industry employment, and offers a discussion of studies focussing on final demand as an explanation of higher service shares in GDP. It also provides an overview of studies analyzing the inter-industry division of labor on the basis of input-output data. Finally, it discusses studies following Baumol's cost-disease hypothesis.

JEL Classification: E2, J2, J3, L0, L8, O1, O3, O4, N1

Keywords: structural economic change, service industries, economic development, productivity, employment

Corresponding author:

Ronald Schettkat

Russell Sage Foundation

112 East 64th Street

New York, NY 10021

USA

Email: ronald.schettkat@rsage.org

Tel.: +1 (212) 7506048 


\section{Introduction}

'The transition from an agricultural to an industrial economy, which began in England and has been repeated in most of the Western world, has been characterized as a "revolution". The shift from industrial to service employment, which has advanced furthest in the United States but is evident in all developed economies, has proceeded more quietly, but it too has implications for society, and for economic analysis, of "revolutionary" proportions' (Fuchs 1968: 2).

At the dawn of the $21^{\text {st }}$ century, all highly industrialized countries have become 'service economies', at least when measured in terms of the share of the workforce employed in service industries. The 'revolutionary proportions' of which Victor Fuchs spoke in his influential 1968 NBER study 'The Service Economy', have become increasingly visible, and over long periods of time, net employment growth has been absorbed almost entirely by service industries. In the 1960's, the United States already took the lead in the shift of employment to services, and it has since kept this leading role since. To exemplify, in 2000, $74 \%$ of the US workforce was employed in services, compared to $71 \%$ in the UK, $71 \%$ in France, $62 \%$ in Germany, $72 \%$ in the Netherlands ${ }^{1}$ and $63 \%$ in Spain (OECD, 2000).

Although the revolution of the structure of employment has reached unprecedented proportions, a full understanding of the factors accounting for the continuous shift to service industry employment is still lacking. In his 'Conditions of Economic Progress' (1940, a second completely rewritten edition was published in 1951), Colin Clark argues that final demand will increasingly shift to services, thereby raising the share of employment in service industries. Clark based his analysis on the so-called 'hierarchy of needs' hypothesis, which states that services satisfy higher needs than goods, and that, as income grows, a higher share of income will be used for the purchase of services. Following this hypothesis, today's share of service industry employment is higher than in the past because societies demand more services as their income rises, meaning that employment in services will be higher in countries with a higher per capita income. Since per capita income is higher in the US than in other countries, the 
US will have a higher share of service industry employment, and also a higher demand for services.

This 'demand-side' explanation of the shift of employment to the service is challenged by the 'supply-side' interpretation of William Baumol (1967, 2001). According to Baumol, the shift to service industry employment does not result from changing final demand, but from differential productivity growth. His assumption is that, when measured in constant prices, the demand for services and goods is independent of income and that, consequently, the share of services in total output is constant over time and between countries. However, since service sector productivity increases less than manufacturing productivity, the share of employment in the service sector will be higher in high-income economies. If wages in the service sector increase in line with an economy's average rate of wage growth, then the share of services in nominal output will also rise with income. Such an increase would, however, not reflect a greater desire for services, but rather 'technological stagnancy' of service production. ${ }^{2}$

A third explanation of the rising share of employment in the service sector focuses on the inter-industry division of labor. According to this explanation, manufacturing industries increasingly outsource their service activities to firms specialized in the provision of such services. Since the National Income and Product Accounts (NIPA) classify firms according to their main product, the performance of identical tasks will be classified as manufacturing employment when carried out by a manufacturing firm, and as service employment when carried out by a specialized service firm. Thus, in the NIPA, workers are classified, not according to the characteristics of the activity they carry out, but rather on the basis of the location of their workplace. To exemplify, in the NIPA, a marketing manager working in a car factory will be counted as a 'manufacturing' employee, whereas a marketing manager performing exactly the same tasks for a specialized marketing firm, will be counted as a 'service' employee. Thus, as manufacturing firms specialize and outsource their service activities, the share of service industry employment will increase, while this may merely be the result of the reallocation of activities. As in Baumol's cost-disease thesis, service industry

\footnotetext{
${ }^{1}$ In the Netherlands, part-time employment is very common, and is mainly concentrated in service industries.
} 
employment - when measured by NIPA indicators - can rise even if the share of services in final demand remains constant.

In short, the expansion of service industry employment may be the result of:

(A) a shift in the structure of final demand from goods to services;

(B) changes in the inter-industry division of labor, favoring specialized service activities rising; or

(C) inter-industry productivity differentials.

Each of these three dimensions has extensively been analyzed in the literature on the changing employment structure of the highly industrialized economies. In this paper they will be used as the starting point for classifying existing studies on the shift to services. Firstly, however, an overview will be provided of the classics - Fisher (1935), Clark (1940), Fourastié (1949), Baumol (1967, 2001), and Fuchs (1968). Some 'classics' are very comprehensive in their analysis and have served as a reference point for later studies.

2 The third big name in this debate is Jean Fourastie $(1949,1965)$ who argued that low productivity growth in service industries helps to stabilize employment levels. 
Table 1: Dimensions to Be Analyzed To Explain the Shift to Service Employment

\begin{tabular}{|l|l|}
\hline Main dimensions & Sub-Dimensions \\
\hline Final demand & \\
\hline Private consumption & $\begin{array}{l}\text { Household expenditures; } \\
\text { Household structure; } \\
\text { Household income; } \\
\text { Household labor force participation. }\end{array}$ \\
\hline Government consumption & \\
\hline Investment & \\
\hline Exports/imports & $\begin{array}{l}\text { Skills; } \\
\text { Capital-labor ratios; } \\
\text { Industry productivity }\end{array}$ \\
Working hours. \\
\hline Inter-industry division of labor & $\begin{array}{l}\text { Input-output structure; } \\
\text { Vertically integrated sectors; } \\
\text { Final-product employment. }\end{array}$ \\
\hline
\end{tabular}




\section{The Classics: Allan G.B. Fisher (1935), Colin Clark (1940), Jean Fourastié (1949), William J. Baumol (1967), Victor R. Fuchs (1968)}

Allan Fisher (1935) and Colin Clark (1940) independently of each other proposed the so-called three-sector hypothesis according to which, in the course of economic progress, employment will first shift from agriculture to manufacturing, and then to services. In his work 'The Conditions of Economic Progress', Clark argues that consumer demand will shift to services because the demand for manufacturing goods will be saturated and labor will subsequently move to the service sector. While emphasizing the importance of demand shifts to services, Clark recognizes that differences in productivity growth are another major force behind employment shifts. His argument is that labor will be reallocated from manufacturing industries, which experience high rates of productivity growth but stagnating demand, to services, which experience lower rates of productivity growth but rising demand. Clark's assumption is based on detailed empirical data for a large number of countries, including not only employment but also aggregate expenditure figures. For Jean Fourastié (1949), the low rate of productivity growth in services, combined with a shift in demand to services, would be the great hope for $20^{\text {th }}$ century employment. Like Fisher and Clark, Fourastié argued that, in the process of economic development, employment would first shift from agricultural production to manufacturing and then to services. Although Fourastié's analysis is less data based than Clark's study, he does provide data in support of his arguments.

In 1966, William J. Baumol and William G. Bowen wrote a book on the cost disease of the performing arts. A year later, Baumol generalized their main argument in an article titled 'Macroeconomics of Unbalanced Growth: The Anatomy of Urban Crisis' (a more recent application of his fundamental hypothesis can be found in Baumol 2001). The main difference between Baumol and 'the classics' just discussed is that Baumol assumes that the share of services and goods in real output is constant over time, and the same across countries, as implied by his reference to the cross-country study of Summers (1985). According to Baumol's model, the share of service sector employment is larger in high-income countries, and grows with rising income, because of the low productivity level of the service sector (in the cross section), combined with its low productivity growth from a longitudinal perspective. In other words, Baumol 
explains the expansion of service employment in terms of a productivity differential, a constant share of services in real output, and rising income (higher income in crosscountry studies).

It may be misleading, though, to argue that the share of services in real output is the same in a cross-country analysis, because a given nominal output structure, which is, of course, not independent of a country's price structure, is expressed in international prices (see Schettkat 2002). When looking at the share of services in real output over time, it can be argued that in many countries the share of services in real output was more or less constant until the mid-1970s, and has since been increasing (Appelbaum/Schettkat 1999). However, Appelbaum/Schettkat (1999) argue that the 'constancy of services' hypothesis only holds if the price elasticity of demand for services is zero, or if the negative effects of price elasticity are exactly offset by the positive demand effects of rising income (income elasticity). But this will be the exception rather than the rule.

Victor Fuchs (1968) has written one of the most comprehensive studies on the expansion of service employment. He carefully analyzes various data sources and looks at the demand side of the story by means of, among others, household budget surveys. His findings support Baumol's cost-disease hypothesis according to which demand shifts play only a minor role and the share of service employment is mainly increasing because productivity growth in services is lagging. Analyzing consumption data for 48 US states over the period 1938 to 1958 (using data on household expenditures from NIPA), Fuchs finds that the income elasticity of goods is 0.97 and of personal services 1.12 (current prices, assuming identical rates of inflation in each state). Using data from the Consumer Expenditures Survey 1960-1961 gives similar results: an income elasticity for goods of 0.93 (for goods without food/tobacco of 1.05), and for services of 1.12. The income elasticity for spending of local governments is also just above one $(1.07)^{3}$.

${ }^{3}$ Curtis and Murthy (1998: 778) estimate income and price elasticities based on annual NIPA data for the USA, France and Germany (1977-92) and get the following results (t-values in parentheses):

\begin{tabular}{|l|l|l|l|l|}
\hline \multirow{2}{*}{ Country } & Price elasticity & Income elasticity \\
\cline { 2 - 5 } & Lowest & Highest & Lowest & Highest \\
\hline USA & $-0.53(2.40)$ & $-0.47(2.42)$ & $1.57(7.34)$ & $1.60(7.12)$ \\
\hline France & $-0.16(0.92)$ & $-0.13(0.90)$ & $1.49(15.87)$ & $1.56(6.35)$ \\
\hline Germany & $-0.08(2.06)$ & $-0.08(1.89)$ & $0.99(7.31)$ & $1.03(3.02)$ \\
\hline
\end{tabular}


Interestingly, Fuchs also analyzes causes of the slower productivity growth in services as compared to manufacturing. He corrects his labor productivity measures (output per person employed) for so-called 'labor inputs', such as hours worked and skills. He estimates that service sector productivity growth lags behind manufacturing productivity growth mainly because skill-upgrading has been less pronounced in services, although this cannot fully explain the productivity growth differential between services and manufacturing. Fuchs estimates that the $0.6 \%$-point differences between the employment growth rate in services and in manufacturing results from an $0.1 \%$ point larger reduction in working hours in services, an $0.3 \%$-point lower rate of skillupgrading in services, and an $0.2 \%$-point smaller rise in capital intensity in services. According to Fuchs, using the nominal share of services in nominal output will give an overestimation of the shift to services, and the share of services in real output an underestimation ${ }^{4}$. The 'truth' will lie somewhere in between.

Of the five 'classics', Fuchs' study is by far the most comprehensive and refined, at least as far as the analysis of empirical evidence is concerned. His work confirms Baumol's claim that the shift to services is largely the result of productivity differentials, and that demand shifts are insufficient to explain the phenomenon of growing employment in service industries.

\footnotetext{
${ }^{5}$ The major argument is that quality changes in services are underestimated, and thus, that inflation is overestimated (see also section 7 below which deals with cost disease studies)
} 
Table 2: Overview of 'The Classics'

\begin{tabular}{|c|c|c|c|c|c|}
\hline \multirow[t]{2}{*}{ Dimensions } & \multicolumn{5}{|c|}{ Study } \\
\hline & Fisher & Clark & Fourastié & Baumol & Fuchs \\
\hline Period & $\pm 1850-1930$ & $\pm 1850-1945$ & $\pm 1800-1950$ & $1948-1995$ & $1929-1965$ \\
\hline Countries & $\begin{array}{l}\text { Reference to } \\
\text { Australia, US, } \\
\text { UK, Germany, } \\
\text { France, } \\
\text { Belgium, } \\
\text { China }\end{array}$ & $\begin{array}{l}\text { US \& over } 30 \\
\text { other countries }\end{array}$ & US and France & $\begin{array}{l}\text { Canada, } \\
\text { Germany, } \\
\text { France, Japan, } \\
\text { UK, US }\end{array}$ & US \\
\hline Employm. & $\begin{array}{l}\text { Employment } \\
\text { shifts from } \\
\text { primary } \\
\text { (agriculture) to } \\
\text { secondary } \\
\text { (manufacturin } \\
\text { g) to tertiary } \\
\text { (services) }\end{array}$ & $\begin{array}{l}\text { Employment } \\
\text { shifts from } \\
\text { agriculture to } \\
\text { manufacturing } \\
\text { and then to } \\
\text { services }\end{array}$ & $\begin{array}{l}\text { Rising because } \\
\text { of lagging } \\
\text { productivity } \\
\text { growth and } \\
\text { shifts in } \\
\text { demand }\end{array}$ & $\begin{array}{l}\text { Rising because } \\
\text { some services } \\
\text { are technologi- } \\
\text { cally stagnant } \\
\text { and demand is } \\
\text { price inelastic } \\
\text { but income } \\
\text { elasticity is } \\
\text { one }\end{array}$ & $\begin{array}{l}\text { Rising because } \\
\text { of lagging } \\
\text { productivity } \\
\text { growth; } \\
\text { demand shifts } \\
\text { play only a } \\
\text { minor role. }\end{array}$ \\
\hline Final Demand & $\begin{array}{l}\text { Services are } \\
\text { luxury (income } \\
\text { elasticity } \\
\text { greater than 1) } \\
\text { and absorb an } \\
\text { increasing } \\
\text { share of } \\
\text { expenditures. }\end{array}$ & $\begin{array}{l}\text { As economies } \\
\text { evolve, } \\
\text { demand for } \\
\text { manufactures } \\
\text { tends to settle } \\
\text { at } 20-25 \% \text {; } \\
\text { for agricultural } \\
\text { products at } \\
10 \% \text { and hence } \\
\text { for services at } \\
70 \% \text { of GDP }\end{array}$ & & $\begin{array}{l}\text { Constant share } \\
\text { of services in } \\
\text { real output and } \\
\text { demand }\end{array}$ & $\begin{array}{l}\text { Constant share } \\
\text { of services in } \\
\text { real output. }\end{array}$ \\
\hline $\begin{array}{l}\text { Private } \\
\text { consumption/ } \\
\text { Household } \\
\text { expenditures }\end{array}$ & $\begin{array}{l}\text { Engel's Law, } \\
\text { 'manufacturin } \\
\mathrm{g} \text { problem } \\
\text { solved', } \\
\text { saturation in } \\
\text { goods markets, } \\
\text { problem of the } \\
4^{\text {th } \text { decade of }} \\
20^{\text {th }} \text { century to } \\
\text { transfer } \\
\text { resources into } \\
\text { services }\end{array}$ & $\begin{array}{l}\text { Engel's Law; } \\
\text { saturation of } \\
\text { demand for } \\
\text { manufactures; } \\
\text { growing } \\
\text { demand for } \\
\text { services }\end{array}$ & $\begin{array}{l}\text { Engel's Law; } \\
\text { Potential } \\
\text { saturation of } \\
\text { demand for } \\
\text { manufactures; } \\
\text { insatiable } \\
\text { demand for } \\
\text { services }\end{array}$ & & 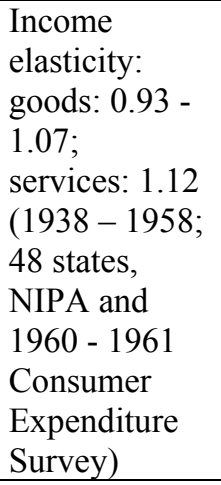 \\
\hline $\begin{array}{l}\text { Government } \\
\text { consumption }\end{array}$ & & & & & $\begin{array}{l}\text { Income } \\
\text { elasticity for } \\
\text { state and local } \\
\text { Government } \\
\text { expenditure: } \\
1.07\end{array}$ \\
\hline Investment & & & & & \\
\hline
\end{tabular}




\begin{tabular}{|c|c|c|c|c|c|}
\hline $\begin{array}{l}\text { Imports/ } \\
\text { Exports }\end{array}$ & & & & & \\
\hline $\begin{array}{l}\text { Industry } \\
\text { Productivity }\end{array}$ & $\begin{array}{l}\text { Grows more } \\
\text { than demand, } \\
\text { which makes } \\
\text { the transfer of } \\
\text { resources to } \\
\text { services } \\
\text { necessary. } \\
\text { This process } \\
\text { causes } \\
\text { frictions. }\end{array}$ & $\begin{array}{l}\text { Real product } \\
\text { per man-hour } \\
\text { in agriculture } \\
\text { is lower than } \\
\text { in secondary } \\
\text { and tertiary } \\
\text { industry; real } \\
\text { product in } \\
\text { secondary and } \\
\text { tertiary } \\
\text { industry often } \\
\text { go hand in } \\
\text { hand }\end{array}$ & & $\begin{array}{l}\text { Some services } \\
\text { (although not } \\
\text { all) are techno- } \\
\text { logically } \\
\text { stagnant and } \\
\text { suffer from } \\
\text { cost disease }\end{array}$ & $\begin{array}{l}\text { Services suffer } \\
\text { from lagging } \\
\text { productivity } \\
\text { due to lack of } \\
\text { skill upgrading } \\
\text { and longer } \\
\text { working hours }\end{array}$ \\
\hline $\begin{array}{l}\text { Inter-ind. } \\
\text { division of } \\
\text { labor }\end{array}$ & & & & & $\begin{array}{l}\text { Intermediate } \\
\text { service } \\
\text { demand has } \\
\text { increased }\end{array}$ \\
\hline Summary & $\begin{array}{l}\text { Three stages of } \\
\text { economic } \\
\text { development: } \\
\text { primary, } \\
\text { secondary, } \\
\text { tertiary. } \\
\text { Economic } \\
\text { resources shift } \\
\text { to the latter, } \\
\text { consumer } \\
\text { demand rises } \\
\text { in services. }\end{array}$ & $\begin{array}{l}\text { Inter-country } \\
\text { differences in } \\
\text { employment } \\
\text { structure are } \\
\text { the result of } \\
\text { relative } \\
\text { changes in } \\
\text { demand and an } \\
\text { employment } \\
\text { shift from } \\
\text { more produc- } \\
\text { tive to less } \\
\text { productive } \\
\text { industries }\end{array}$ & $\begin{array}{l}\text { Due to slow } \\
\text { technical } \\
\text { progress, } \\
\text { service sector } \\
\text { productivity is } \\
\text { low, and } \\
\text { hence, } \\
\text { employment } \\
\text { shifts to } \\
\text { services. } \\
\text { Demand shifts } \\
\text { also play a } \\
\text { minor role }\end{array}$ & & $\begin{array}{l}\text { Services have } \\
0.6 \% \text { higher } \\
\text { employment } \\
\text { growth than } \\
\text { manufacturing; } \\
0.1 \% \text { faster } \\
\text { reduction in } \\
\text { working hours; } \\
0.3 \% \text { greater } \\
\text { increase in } \\
\text { skills; } \\
\text { Manufacturing } \\
\text { has: } \\
0.2 \% \text { higher } \\
\text { rise in capital } \\
\text { intensity; } \\
0.4 \% \text { faster } \\
\text { technological } \\
\text { progress }\end{array}$ \\
\hline Data & $\begin{array}{l}\text { Citation of } \\
\text { budget } \\
\text { surveys. }\end{array}$ & $\begin{array}{l}\text { Innumerable } \\
\text { sources }\end{array}$ & $\begin{array}{l}\text { Commissariat } \\
\text { Général au } \\
\text { Plan; Clark } \\
(1940) \text {; etc. }\end{array}$ & $\begin{array}{l}\text { CPI Detailed } \\
\text { Reports; } \\
\text { Summers } \\
\text { 1985; OECD }\end{array}$ & $\begin{array}{l}\text { US Census of } \\
\text { Population and } \\
\text { Housing; } \\
\text { Consumer } \\
\text { Expenditure } \\
\text { Survey; NIPA }\end{array}$ \\
\hline Method & $\begin{array}{l}\text { Theoretical, } \\
\text { Historical }\end{array}$ & $\begin{array}{l}\text { Econometric, } \\
\text { Historical }\end{array}$ & $\begin{array}{l}\text { Theoretical, } \\
\text { Descriptive }\end{array}$ & $\begin{array}{l}\text { Theoretical, } \\
\text { Econometric }\end{array}$ & Econometric \\
\hline
\end{tabular}




\section{Studies Analyzing the Employment Structure by Regrouping Industries}

A number of studies have attempted to develop a better understanding of the expansion of service employment by regrouping or reclassifying service industries. Such a reclassification exercise is usually based on the idea that service demand is related to the purpose of a service (consumer vs. business services), or to the form of its provision (market /private vs. public provision), but also on the idea that the economic effects of expanding service employment depend on the information and knowledge content of different services. The distinction on the basis of technological progress is also important, though mostly made implicitly. More specifically, services can be reclassified on the basis of whether they are related to the distribution of goods (e.g, trade and transport), are mainly used as inputs for goods production (e.g., banking, insurance, and engineering), or are remaining services, which can be divided into social services (e.g., health services, education), and personal services (e.g., restaurants, hotels, barber and beauty shops). This fourfold classification of services was first developed by Katouzian (1970), but has subsequently been altered and used in the studies of Singelmann (1978), Castells (1996) and Elfring (1988, 1989)

Scharpf (1996: 26) regroups ISIC 7 (transport, storage and communication) and ISIC 8 (finance, insurance, real estate and business services) together under producer services, and ISIC 6 (trade, restaurants and hotels) and ISIC 9 (community, social and personal services) under private or consumer services. Scharpf explicitly regards this as a rough approximation of the underlying distinction between goods-related production and service demand. Scharpf's classification is highly similar to Singelmann's original version, but is not an exact reproduction. Scharpf finds that, whereas the employmentpopulation rate of 'goods-related' industries is very similar across most industrialized countries, the employment-population rate for private services differs substantially. His explanation is that internationally traded goods are produced with roughly similar labor inputs, and are demanded in roughly similar quantities, in all industrialized countries. This implies that only differences in the degree of specialization (outsourcing) affect the distribution of employment between manufacturing and producer services.

\footnotetext{
${ }^{5}$ The acronym ISIC stands for International Standard Industry Classification
} 
In Scharpf's view, differences between 'private-service employment' shares in the working-age population partly result from labor costs, which are, in turn, influenced by a country's welfare state regime.

Most reclassification studies use Singelmann's detailed classification, which has been reproduced in Table 3. Singelmann distinguishes, amongst other, between 'distributive services' and 'producer services', which together comprise the services that are related to the production process. The latter of these two categories, however, includes not only services that serve as inputs for 'goods production' but also services that are used as intermediate inputs for service production or are demanded for direct consumption (Greenhalgh/Gregory 2001, Russo/ Schettkat 1998, 2001). When using NIPA data, it is difficult to make a clear-cut distinction between consumer and producer services, as Singelmann proposes. To give an example, the sector banking and financial services (11 in Singelmann's classification) provides both intermediate and final services. However, as shown in Table 3, in the US, the banking sector in fact provides $50.7 \%$ of its output for use by other producers, and $49.3 \%$ for final household consumption.

It would therefore be far more appropriate to make a distinction on the basis of different user categories of industry outputs (that is, intermediate demand, private consumption, government consumption, investment, and exports) and their relation to employment. Such a classification is offered, for example, by the Final Product concept. The Final Product concept summarizes all productive activities necessary to produce one item of output, and thus, allows for a clear division of employment according to specific demand categories. It also renders it possible to distinguish between the various components of final demand (Russo/ Schettkat 1998). 
Table 3: An Extended Sectoral Classification Scheme (Browning-Singelmann) Industry

\section{Extractive}

(1) Agriculture, fishing and forestry

(2) Mining

II. Transformative

(3) Construction

(4) Food

(5) Textile

(6) Metal

(7) Machinery

(8) Chemical

(9) Miscellaneous manufacturing

(10) Utilities

\section{Distributive Services}

(11) Transportation and storage

(12) Communication

(13) Wholesale trade

(14) Retail trade (except eating and drinking)

IV. Producer Services

(15) Banking, credit, and other financial service

(16) Insurance

(17) Real estate

(18) Engineering and architectural services

(19) Accounting and bookkeeping

(20) Miscellaneous business services

(21) Legal services**

V. Social Services

(22) Medical and health services

(23) Hospitals

(24) Education

(25) Welfare and religious organizations

(26) Non-profit organizations***

(27) Postal services

(28) Government

(29) Miscellaneous ${ }^{\wedge}$

VI. Personal Services

(30) Domestic services***

(31) Hotels and lodging

(32) Eating and drinking places

(33) Repair services

(34) Laundry and dry cleaning

(35) Barber and beauty shops

(36) Entertainment and recreational services

(37) Miscellaneous personal services
ISIC

Rev. 2

.

Share of final consumer demand in gross output (1995)

\begin{tabular}{|c|c|c|c|c|c|}
\hline US* & $\mathbf{U K}^{\wedge}$ & $\mathbf{F}$ & G & NL & ES \\
\hline 9.4 & 29.0 & 19.6 & 18.7 & 3.5 & 2.0 \\
\hline 1.5 & 1.0 & 1.8 & 12.0 & 0.1 & 2.3 \\
\hline 0.0 & 3.5 & 5.0 & 2.0 & 0.7 & 2.8 \\
\hline 56.5 & 59.7 & 55.4 & 56.7 & 19.5 & 40.8 \\
\hline 42.8 & 39.1 & 35.6 & 42.3 & 28.7 & 35.9 \\
\hline 2.3 & 2.0 & 1.3 & 3.9 & 0.2 & 1.7 \\
\hline 14.6 & 11.2 & 15.9 & 11.1 & 2.3 & 9.7 \\
\hline 22.8 & 11.8 & 14.8 & 11.8 & 0.9 & 11.7 \\
\hline 14.4 & 20.7 & 19.4 & 16.4 & 8.9 & 15.7 \\
\hline 38.3 & 34.1 & 43.2 & 37.2 & 34.5 & 28.8 \\
\hline 24.4 & 18.8 & 26.8 & 30.7 & 19.5 & 22.0 \\
\hline 37.1 & 24.3 & 34.1 & 39.0 & 27.8 & 32.8 \\
\hline 53.9 & 63.7 & 59.3 & 53.0 & 38.4 & 58.2 \\
\hline 53.9 & 63.7 & 59.3 & 53.0 & 38.4 & 58.2 \\
\hline 49.3 & 26.1 & 21.5 & 23.4 & 30.5 & 16.2 \\
\hline 49.3 & 26.1 & 21.5 & 23.4 & 30.5 & 16.2 \\
\hline 63.2 & 67.8 & 71.3 & 63.2 & 74.9 & 81.3 \\
\hline 11.0 & 1.7 & 5.1 & 3.2 & 4.3 & 4.7 \\
\hline 11.0 & 1.7 & 5.1 & 3.2 & 4.3 & 4.7 \\
\hline 10.3 & 5.0 & 4.8 & 3.9 & 4.4 & 7.4 \\
\hline 11.0 & 1.7 & 5.1 & 3.2 & 4.3 & 4.7 \\
\hline 107.9\# & 9.0 & 23.5 & 22.0 & 23.8 & 25.1 \\
\hline 107.9\# & 9.0 & 23.5 & 22.0 & 23.8 & 25.1 \\
\hline $112.5 \#$ & 13.2 & 7.9 & 10.5 & 3.3 & 23.0 \\
\hline 62.6 & 48.7 & 55.7 & 37.1 & 26.1 & 53.5 \\
\hline 100.0 & 99.2 & 100.0 & 100.0 & 100.0 & 100.0 \\
\hline 37.1 & 24.3 & 34.1 & 39.0 & 27.8 & 32.8 \\
\hline 6.4 & 5.1 & 0.1 & 1.1 & 5.3 & 2.5 \\
\hline 62.6 & 48.7 & 55.7 & 37.1 & 26.1 & 53.5 \\
\hline 100.0 & 99.2 & 100.0 & 100.0 & 100.0 & 100.0 \\
\hline 80.0 & 74.4 & 84.0 & 81.3 & 54.2 & 91.1 \\
\hline 80.0 & 74.4 & 84.0 & 81.3 & 54.2 & 91.1 \\
\hline 53.9 & 63.7 & 59.3 & 53.0 & 38.4 & 58.2 \\
\hline 62.6 & 48.7 & 55.7 & 37.1 & 26.1 & 53.5 \\
\hline 62.6 & 48.7 & 55.7 & 37.1 & 26.1 & 53.5 \\
\hline 62.6 & 48.7 & 55.7 & 37.1 & 26.1 & 53.5 \\
\hline 62.6 & 48.7 & 55.7 & 37.1 & 26.1 & 53.5 \\
\hline
\end{tabular}

Source: Classification from Singelmann (1978: 31). Shares computed from the 1995 OECD Input-Output database.

*US; year=1997, ^UK; year=1998, **(21)Legal services together with (18) and (19) ^^ (25)welfare and religious services, (29) miscellaneous professional and social services and (37) miscellaneous personal services cannot be split ***(26)non-profit organisations and (30) domestic services cannot be split \# $>100$ because negative government spending in Input-Outpu data. 
Castells (1996: 296) uses Singelmann's classification and labeling, but, in addition, distinguishes between information-processing (communications, finance, insurance, real estate, services government) and goods-handling activities (mining, construction, manufacturing, wholesale/retail trade). On the basis of this distinction, he constructs two indices: service-delivery employment/goods-producing employment; and information-processing employment/goods-handling employment.

Looking at the ratio of information-processing employment to goods-handling employment, Castells concludes that, on the basis of its employment structure, the US is a service-producing economy rather than a distinctively information-processing economy. The United Kingdom, Canada and France have nearly the same ratio as the US, and although Germany and Italy have substantially lower ratios, their informationprocessing employment has been growing. This implies that the trend towards more information-processing is not merely an American phenomenon but can be observed in all countries studied (Castells, 1996: 210).

Castells' reclassification exercise appears related to earlier efforts by Machlup (1962) and Porat (1977), who distinguished an information sector comprising industries producing information machines, industries transforming, communicating or transporting information, and industries selling information services. Apart from private industries, this information sector also included public $R \& D$, education, postal services and public administration.

A regrouping of industries on the basis of information and knowledge content can give a classification like the one shown in Table 4. Using this classification, Albin and Appelbaum (1990) conclude that employment in information and communication services and manufacturing was growing at a higher rate than 'other' manufacturing ${ }^{6}$ or 'other' service ${ }^{7}$ industries.

\footnotetext{
${ }^{6}$ The category 'other' manufacturing industries comprises construction, other durable goods and nondurable goods manufacturing, transportation and public utilities.

${ }^{7}$ The category 'other' services encompasses hospitals, other health services, social welfare services, personal and recreational services, private household services, eating and drinking places and hotels, vehicle sales, retail trade, wholesale trade, automobile service and repair, and guard, cleaning and repair services.
} 
Table 4: Growth Rates of Regrouped Industries According to their Information and Knowledge Content (1973 - 1987)

\begin{tabular}{|l|cc|ccc|c|}
\hline & \multicolumn{2}{|c|}{ Employment growth } & \multicolumn{2}{c|}{ Output growth } & \multicolumn{2}{c|}{ Implied product. growth } \\
& $\mathbf{1 9 7 3 - 7 9}$ & $\mathbf{1 9 7 9 - 8 7}$ & $\mathbf{1 9 7 3 - 7 9}$ & $\mathbf{1 9 7 9 - 8 7}$ & $\mathbf{1 9 7 3 - 7 9}$ & $\mathbf{1 9 7 9 - 8 7}$ \\
\hline Extractive industries & 0 & 0.3 & 0.2 & 0.4 & 0.2 & 0.1 \\
Info/Knowledge & 3 & 1.1 & 4.4 & 2.8 & 1.4 & 1.7 \\
Manufacturing & & & & & & \\
Other Industry & 1.3 & 0 & 1.4 & 1.6 & 0.1 & 1.6 \\
Info/Knowledge Services & 3.5 & 3 & 3.2 & 2.8 & -0.3 & -0.2 \\
Other Services & 2.8 & 2.5 & 3.3 & 2.9 & 0.5 & 0.4 \\
\hline
\end{tabular}

Implied productivity growth is computed as the rate of output growth minus the rate of employment growth. Information/knowledge services include imputed housing.

Source: Albin/Appelbaum 1990: 42/43

In the view of Albin/Appelbaum, '[t]he de-industrialization thesis - that the small size of the information and knowledge manufacturing sector and the decline of employment in other manufacturing industries implies a shift to a low-wage, low productivity growth economy- also misses the main point. What emerges from our analysis is that the shift to employment in service industries has resulted in increasing dualism in the U.S. economy' (Albin/ Appelbaum 1990: 40).

Surprisingly, the information and knowledge services do not experience higher productivity growth according to the analysis of Albin/Appelbaum, and even suffer from negative productivity growth. This may be an indication that the distinction between technologically stagnant and technologically progressive services is not identical to the distinction between services on the basis of their information and knowledge content. ${ }^{8}$ It may, however, also be an indication of the measurement problems to which service tend to be subject (Griliches, 1992).

Another way of investigating the changing size of the service sector is by dividing the economy into a service- and a goods-producing sector on the basis of service occupations rather than service industries. The advantage of this approach is that it identifies all service activities, irrespective of the industry in which they are carried out, thereby capturing the increasing 'tertiarization' of the goods production process. Freeman and Schettkat (1999) performed such an analysis, albeit for different purposes,

\footnotetext{
${ }^{8}$ Albin and Appelbaum point out that the information and knowledge industries are paying higher mean wages. This result, however, is based on raw wage data, which has not been controlled for skill levels (which are higher in these industries).
} 
on the basis of the Comparative German American Database. For the sake of comparability, this database classifies occupations and industries in the US and German economies on the basis of identical categories. Table 5 displays the results of the Freeman/ Schettkat analysis.

Table 5: Employment shares in service and manufacturing industries and in servicing and producing occupations (\%)

\begin{tabular}{|c|c|c|c|c|c|c|}
\hline & \multicolumn{2}{|c|}{ Germany (West) } & \multicolumn{2}{|c|}{$\mathbf{U S}$} & \multicolumn{2}{|c|}{ Germany - USA } \\
\hline & Industries & $\begin{array}{c}\text { Occu- } \\
\text { pations }\end{array}$ & Industries & $\begin{array}{c}\text { Occu- } \\
\text { pations }\end{array}$ & Industries & $\begin{array}{c}\text { Occu- } \\
\text { pations }\end{array}$ \\
\hline \multicolumn{7}{|c|}{ Weighted by persons employed } \\
\hline $\begin{array}{l}\text { Services/ } \\
\text { Servicing }\end{array}$ & 61 & 68 & 75 & 78 & -13 & -10 \\
\hline \multicolumn{7}{|c|}{ Weighted by hours worked (full-time equivalents) } \\
\hline $\begin{array}{l}\text { Services/ } \\
\text { Servicing }\end{array}$ & 60 & 67 & 73 & 76 & -13 & -10 \\
\hline
\end{tabular}

Source: Freeman/ Schettkat 1999.

The Freeman/Schettkat results show that in Germany, 68\% of persons employed perform service activities, while only $61 \%$ of employment is accounted for by service industries. This implies that some employees in the goods-producing industries perform service tasks and/or that some employees in service industries are involved in production activities. The discrepancy between the share of employment in service industries and the share involved in performing service tasks is slightly higher in Germany than in the US. Thus, the two economies differ less with regard to service employment when this is expressed in terms of persons involved in service occupations rather when expressed in terms of persons employed in service industries. The difference still remains around $10 \%$-points, however. 
Table 6: Overview of Studies Treating Employment Structure

\begin{tabular}{|c|c|c|c|c|c|c|}
\hline Dimensions & \multicolumn{6}{|c|}{ Study } \\
\hline & Elfring & Scharpf & Singelmann & Castells & $\begin{array}{l}\text { Albin/ } \\
\text { Appelbaum }\end{array}$ & $\begin{array}{l}\text { Freeman/ } \\
\text { Schettkat }\end{array}$ \\
\hline Period & $1960-1984$ & $1970-1981$ & $1920-1970$ & $1920-1990$ & $1973-1987$ & 1970-1999 \\
\hline Countries & $\begin{array}{l}\text { France, } \\
\text { Germany, } \\
\text { Japan, NL, } \\
\text { UK and US }\end{array}$ & $\begin{array}{l}\text { Australia, } \\
\text { Austria, } \\
\text { Belg., Can., } \\
\text { Denm., Fr., } \\
\text { Germ., Jap., } \\
\text { NL, Norw., } \\
\text { Swe, Switz., } \\
\text { UK and US }\end{array}$ & $\begin{array}{l}\text { Canada, } \\
\text { England \& } \\
\text { Wales, } \\
\text { France, } \\
\text { Germany, } \\
\text { Italy, Japan, } \\
\text { US }\end{array}$ & $\begin{array}{l}\text { Canada, } \\
\text { France, } \\
\text { Germany, } \\
\text { Italy, Japan, } \\
\text { UK and US }\end{array}$ & US & $\begin{array}{l}\text { US and } \\
\text { West- } \\
\text { Germany }\end{array}$ \\
\hline Employm. & $\begin{array}{l}\text { Rising } \\
\text { steadily }\end{array}$ & $\begin{array}{l}\text { ISIC 2-5 } \\
\text { and } \\
\text { ISIC } 6-9 \\
\text { each } \\
\text { account for } \\
1 / 3 \text { of jobs } \\
\text { of the } \\
\text { working age } \\
\text { population }\end{array}$ & $\begin{array}{l}\text { Rising, but } \\
\text { not } \\
\text { necessarily } \\
\text { sequential } \\
\text { shift from } \\
\text { agriculture } \\
\text { to manufac- } \\
\text { turing to } \\
\text { services } \\
\end{array}$ & $\begin{array}{l}\text { Rising, but } \\
\text { not } \\
\text { necessarily } \\
\text { sequential } \\
\text { shift from } \\
\text { agriculture } \\
\text { to manufac- } \\
\text { turing to } \\
\text { services } \\
\end{array}$ & $\begin{array}{l}\text { Rising, } \\
\text { because } \\
\text { growth in } \\
\text { info- and } \\
\text { knowledge } \\
\text { services lies } \\
\text { above } \\
\text { average }\end{array}$ & $\begin{array}{l}\text { Higher } \\
\text { share of } \\
\text { service } \\
\text { employment } \\
\text { in US than } \\
\text { in West- } \\
\text { Germany }\end{array}$ \\
\hline $\begin{array}{l}\text { Final } \\
\text { Demand }\end{array}$ & $\begin{array}{l}\text { Explains } \\
\text { service } \\
\text { growth for } \pm \\
20-30 \%, \\
\text { and for } 45 \% \\
\text { in Germany }\end{array}$ & & $\begin{array}{l}\text { Among } \\
\text { advanced } \\
\text { countries, } \\
\text { the higher } \\
\text { GDP/Capita } \\
\text { (US\$), the } \\
\text { higher the } \\
\text { demand for } \\
\text { services }\end{array}$ & & & \\
\hline $\begin{array}{l}\text { Private } \\
\text { consump./ } \\
\text { Household } \\
\text { expenditure }\end{array}$ & $\begin{array}{l}\text { Final exp- } \\
\text { enditure on } \\
\text { private } \\
\text { services as a } \\
\text { share of } \\
\text { GDP (con- } \\
\text { stant prices) } \\
\text { increased on } \\
\text { average by } \\
1.5 \% \\
(1973-1984)\end{array}$ & $\begin{array}{l}\text { Private } \\
\text { demand is } \\
\text { influenced } \\
\text { by the } \\
\text { degree of } \\
\text { income } \\
\text { inequality } \\
\text { and by the } \\
\text { public } \\
\text { burden }\end{array}$ & & & & $\begin{array}{l}\text { Higher } \\
\text { share of } \\
\text { non-medical } \\
\text { expenses on } \\
\text { services in } \\
\text { US }\end{array}$ \\
\hline $\begin{array}{l}\text { Government } \\
\text { consump. }\end{array}$ & $\begin{array}{l}\text { Fin. exp. on } \\
\text { government } \\
\text { Services as } \\
\text { a share of } \\
\text { GDP (const. } \\
\text { prices) } \\
\text { increased by } \\
2.1 \% \text {, but } \\
\text { declined in } \\
\text { the US } \\
(1973-1984)\end{array}$ & & & & & \\
\hline Investment & & & & & & \\
\hline
\end{tabular}




\begin{tabular}{|c|c|c|c|c|c|c|}
\hline \multicolumn{7}{|l|}{$\begin{array}{l}\text { Imports/ } \\
\text { Exports }\end{array}$} \\
\hline $\begin{array}{l}\text { Industry } \\
\text { Product. }\end{array}$ & 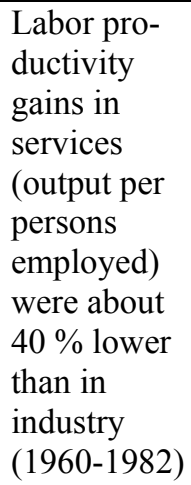 & & & & & \\
\hline \multicolumn{7}{|l|}{$\begin{array}{l}\text { Inter-ind. } \\
\text { division of } \\
\text { labor }\end{array}$} \\
\hline Summary & $\begin{array}{l}\text { In 1960s, } \\
\text { rising } \\
\text { employment } \\
\text { share of } \\
\text { services was } \\
\text { due to social } \\
\text { services; in } \\
\text { the } 1970 \text { s } \\
\text { and } 1980 \mathrm{~s} \\
\text { to producer } \\
\text { and personal } \\
\text { services } \\
\text { Slow prod. } \\
\text { growth } \\
\text { explains } \\
40-60 \% \text { of } \\
\text { empl. shift } \\
\text { to services; } \\
\text { fin. demand } \\
20-30 \% \text {; } \\
\text { interm. dem. } \\
10-40 \%\end{array}$ & $\begin{array}{l}\text { Canada, } \\
\text { Japan, US, } \\
\text { Switzerland } \\
\text { have high } \\
\text { empl. share } \\
\text { in private } \\
\text { and high } \\
\text { share in } \\
\text { public } \\
\text { services; } \\
\text { Sweden, } \\
\text { Denmark, } \\
\text { the UK and } \\
\text { Norway } \\
\text { have the } \\
\text { opposite; } \\
\text { Austria, } \\
\text { Belgium, } \\
\text { France, } \\
\text { Germany } \\
\text { NL have } \\
\text { low shares } \\
\text { in both }\end{array}$ & $\begin{array}{l}\text { Comparing } \\
\text { the sectoral } \\
\text { transforma- } \\
\text { tion of the } \\
\text { labor force } \\
\text { in seven } \\
\text { countries } \\
\text { reveals that } \\
\text { the shift } \\
\text { from } \\
\text { agriculture } \\
\text { to services } \\
\text { followed a } \\
\text { different } \\
\text { path in } \\
\text { Western } \\
\text { Europe, } \\
\text { North } \\
\text { America } \\
\text { and Japan }\end{array}$ & $\begin{array}{l}\text { Two models } \\
\text { of change: } \\
\text { 1) Service } \\
\text { Economy } \\
\text { Model => } \\
\text { reduction of } \\
\text { manufact. } \\
\text { employment } \\
\text { after 1970; } \\
\text { 2) Industrial } \\
\text { Production } \\
\text { Model => } \\
\text { reduction of } \\
\text { manufact. } \\
\text { employment } \\
\text { but remains } \\
\text { large; } \\
\text { 3) France } \\
\text { and Italy do } \\
\text { not fit either } \\
\text { of these } \\
\text { models }\end{array}$ & $\begin{array}{l}\text { Shift of em- } \\
\text { ployment to } \\
\text { services } \\
\text { leads to } \\
\text { dualism in } \\
\text { US } \\
\text { economy } \\
\text { because } \\
\text { information } \\
\text { and } \\
\text { knowledge } \\
\text { intensive } \\
\text { services } \\
\text { (white } \\
\text { collar) and } \\
\text { 'other' } \\
\text { services } \\
\text { (blue } \\
\text { collar), } \\
\text { increase } \\
\text { simulta- } \\
\text { neously }\end{array}$ & $\begin{array}{l}\text { American } \\
\text { households } \\
\text { spend a } \\
\text { larger share } \\
\text { of their } \\
\text { incomes on } \\
\text { services, } \\
\text { and less } \\
\text { time in } \\
\text { household } \\
\text { production, } \\
\text { than } \\
\text { German } \\
\text { households } \\
\text { do }\end{array}$ \\
\hline Data & $\begin{array}{l}\text { NIPA and } \\
\text { OECD } \\
\text { Historical } \\
\text { Statistics; } \\
\text { National } \\
\text { Population } \\
\text { Census of } \\
\text { different } \\
\text { countries; }\end{array}$ & $\begin{array}{l}\text { NIPA and } \\
\text { OECD LFS; } \\
\text { ILO } \\
\text { Statistical } \\
\text { Yearbook; } \\
\text { OECD } \\
\text { Employm. } \\
\text { in the Public } \\
\text { Sector }\end{array}$ & & $\begin{array}{l}\text { Singelmann } \\
(1920-1970) \\
\text { National } \\
\text { Census Data } \\
(1970-1990)\end{array}$ & $\begin{array}{l}\text { Current } \\
\text { Population } \\
\text { Survey for } \\
\text { March } \\
1973,1979 \text {, } \\
1987\end{array}$ & $\begin{array}{l}\text { NIPA; } \\
\text { comparative } \\
\text { US/German } \\
\text { Structural } \\
\text { Database; } \\
\text { US/German } \\
\text {-Time- } \\
\text { budget } \\
\text { Database }\end{array}$ \\
\hline Method & $\begin{array}{l}\text { Econometr. } \\
\text { Descriptive }\end{array}$ & $\begin{array}{l}\text { Econometr. } \\
\text { Descriptive }\end{array}$ & $\begin{array}{l}\text { Theoretical, } \\
\text { Descriptive }\end{array}$ & Descriptive & $\begin{array}{l}\text { Econometr. } \\
\text { Descriptive }\end{array}$ & Econometr. \\
\hline
\end{tabular}




\section{Studies Analyzing Shifts in Final Demand}

Few studies have attempted explicitly to analyze the structure, and changes in the structure, of final demand. Some studies (implicitly) assume that demand patterns remain unchanged, others that shifts in employment merely reflect changes in demand. Clark (1940) was one of the first to argue that demand shifts are the major cause of expanding service employment.

Summers' work (1985), which is based on the Penn-World tables, explicitly uses the output structure as a proxy for demand of countries at different income levels. Summers shows that, when expressed in national prices - that is, when the national price structure affects output shares - there exists a positive relation between income and the share of services in output. However, when the share of services in overall output is expressed in international prices (PPPs), the positively sloping regression line turns horizontal. On the basis of his cross-country analysis, Summers concludes that the share of services in demand is independent of income. Baumol (2001) uses Summers' study to support his hypothesis that the share of services in real output is constant. International prices are used, however, to eliminate differences in the price structure of different countries while correcting national sales with other prices (that is, the product of quantities and prices measured in national prices), thereby assuming that quantities demanded are independent of prices. The major outcome of such an exercise is inflated service shares for less developed countries. Whether the quantities demanded would have been the same if these countries had had a price structure similar to that of the developed countries remains questionable (Schettkat 2002). Appelbaum and Schettkat (1999) provide evidence from a longitudinal, within-country perspective, which shows that since the $1970 \mathrm{~s}$, the share of services in real output has been increasing in the highly industrialized countries (see also Schettkat 2002).

Fuchs (1968) explicitly analyzes household demand for services and goods. His analysis shows that the demand elasticity for services is slightly higher than that for goods. Fuchs also presents evidence showing that the income elasticity of the demand for goods is influenced by the demand for food. Excluding food from the analysis gives an income elasticity slightly above one, which is roughly similar to the income elasticity for services (Fuchs 1968). Gershuny (1978) analyzes household budget 
surveys for the United Kingdom for the years 1953, 1954, 1961, 1966, 1971 and 1974 and argues that the private consumption of services has dropped because the private demand for services is being substituted by a demand for household appliances. Skolka (1976) presents a similar argument.

Apart from private household consumption, other major demand components (government consumption, exports) also contribute towards explaining shifts in final demand. Fuchs (1968: 42), for example, finds that in the United States, the income elasticity for local government spending is 1.07 .

Rowthorn and Wells (1987), in a discussion of the decline of manufacturing employment in the United Kingdom, argue that a country's trade specialization is the single most important factor explaining differences in the employment structure of advanced country's. That is, countries with a high ratio of net manufactured exports to GDP will have a greater share of employment in manufacturing than countries that are net importers of manufactured goods. This implies that an analysis of the impact of the demand structure on the employment structure cannot be limited to domestic demand and household consumption. 
Table 7: Overview of Studies Analyzing Shifts in Final Demand

\begin{tabular}{|c|c|c|c|c|}
\hline Dimensions & \multicolumn{4}{|c|}{ Study } \\
\hline & Summers & Gershuny & Gershuny/Miles & Rowthorn/Wells \\
\hline Period & 1970 and 1975 & $1953-1974$ & $1963-1978$ & $1952-1982$ \\
\hline Countries & $\begin{array}{l}\text { US and } 33 \text { other } \\
\text { countries }\end{array}$ & UK & $\begin{array}{l}\text { Belgium, } \\
\text { Denmark, France, } \\
\text { Germany, Ireland, } \\
\text { Italy, NL, UK, }\end{array}$ & $\begin{array}{l}\text { UK, but also } \\
\text { Australia, Austria, } \\
\text { Belgium, Canada, } \\
\text { France, Italy, } \\
\text { Japan, NL, } \\
\text { Norway, Sweden, } \\
\text { US, West- } \\
\text { Germany }\end{array}$ \\
\hline Employment & & & $\begin{array}{l}\text { Growth in } \\
\text { intermediary } \\
\text { producer services } \\
\text { and final non- } \\
\text { market services; } \\
\text { decline in many } \\
\text { marketed final } \\
\text { services }\end{array}$ & $\begin{array}{l}\text { Share of } \\
\text { agriculture } \\
\text { declines steadily; } \\
\text { share of services } \\
\text { rises continuously; } \\
\text { share of industry } \\
\text { first rises and then } \\
\text { declines }\end{array}$ \\
\hline Final demand & $\begin{array}{l}\text { Service shares in } \\
\text { GDP as measured } \\
\text { in domestic prices } \\
\text { increase with } \\
\text { country income, } \\
\text { but when } \\
\text { measured in } \\
\text { common prices, } \\
\text { there is no } \\
\text { relationship }\end{array}$ & $\begin{array}{l}\text { If health care and } \\
\text { education are } \\
\text { included, service } \\
\text { expenditure as a } \\
\text { whole has risen } \\
\text { slightly }\end{array}$ & $\begin{array}{l}\text { Price elasticity } \\
\text { leads to stagnation } \\
\text { or decline of many } \\
\text { marketed final } \\
\text { services }\end{array}$ & $\begin{array}{l}\text { In real terms, no } \\
\text { shift in demand } \\
\text { from goods to } \\
\text { services and in } \\
\text { advanced } \\
\text { countries no shift } \\
\text { away from the } \\
\text { demand for } \\
\text { industrial products }\end{array}$ \\
\hline $\begin{array}{l}\text { Private } \\
\text { consumption/ } \\
\text { household } \\
\text { expenditure }\end{array}$ & $\begin{array}{l}\text { For housing-, } \\
\text { medical care, and } \\
\text { other services, } \\
\text { income elasticity } \\
\text { significantly }>1 \text {; } \\
\text { for recreation \& } \\
\text { education }<1 \text {; for } \\
\text { transportation, } \\
\text { communication, } \\
\text { and government } \\
\text { not significantly } \\
\text { different from one }\end{array}$ & $\begin{array}{l}\text { On the basis of } \\
\text { Budget Data from } \\
\text { the Household } \\
\text { Expenditure Data } \\
(1953-1974) \text {, it } \\
\text { is concluded that } \\
\text { the consumption } \\
\text { of services has } \\
\text { dropped }\end{array}$ & & \\
\hline $\begin{array}{l}\text { Government } \\
\text { Consumption }\end{array}$ & & $\begin{array}{l}\text { Considerable } \\
\text { growth in } \\
\text { government } \\
\text { expenditure on } \\
\text { services (1954-- } \\
1974)\end{array}$ & & \\
\hline Investment & & & & \\
\hline
\end{tabular}




\begin{tabular}{|c|c|c|c|c|}
\hline $\begin{array}{l}\text { Imports/ } \\
\text { Exports }\end{array}$ & & & & $\begin{array}{l}\text { Higher ratio of net } \\
\text { manufact. exports } \\
\text { to GDP is related } \\
\text { to larger fraction } \\
\text { of the labor force } \\
\text { in manufacturing }\end{array}$ \\
\hline $\begin{array}{l}\text { Industry } \\
\text { Productivity }\end{array}$ & & $\begin{array}{l}\text { Lower in services } \\
\text { than in } \\
\text { manufacturing }\end{array}$ & $\begin{array}{l}\text { Stagnating in } \\
\text { services, } \\
\text { especially in } \\
\text { private marketed } \\
\text { services }\end{array}$ & $\begin{array}{l}\text { Is lower in } \\
\text { services than in } \\
\text { manufacturing }\end{array}$ \\
\hline $\begin{array}{l}\text { Inter-industry } \\
\text { division of labor }\end{array}$ & & $\begin{array}{l}\text { Intermediate } \\
\text { service demand } \\
\text { has increased }\end{array}$ & $\begin{array}{l}\text { Intermediate } \\
\text { service demand } \\
\text { has increased }\end{array}$ & \\
\hline Summary & $\begin{array}{l}\text { In } 1975 \text {, service } \\
\text { shares were } \\
\text { essentially } \\
\text { unrelated to } \\
\text { income, but over } \\
\text { time they are } \\
\text { rising in poor } \\
\text { countries and } \\
\text { remain essentially } \\
\text { constant in rich } \\
\text { countries }\end{array}$ & $\begin{array}{l}\text { Private } \\
\text { expenditures for } \\
\text { services are } \\
\text { substituted by } \\
\text { household } \\
\text { appliances and } \\
\text { self-service time. }\end{array}$ & & $\begin{array}{l}\text { In a mature } \\
\text { economy, de- } \\
\text { industrialization } \\
\text { can be associated } \\
\text { with both weak } \\
\text { and strong trade } \\
\text { performance => } \\
\text { there is no unique } \\
\text { route, either in } \\
\text { terms of the } \\
\text { structure of } \\
\text { foreign trade, or } \\
\text { its constancy, to } \\
\text { the achievement } \\
\text { of successful } \\
\text { economic } \\
\text { development. } \\
\text { However, } \\
\text { industrialization is } \\
\text { essential for } \\
\text { economic progress }\end{array}$ \\
\hline Data & $\begin{array}{l}\text { United Nations } \\
\text { International } \\
\text { Comparisons } \\
\text { project (ICP) }\end{array}$ & $\begin{array}{l}\text { Census of } \\
\text { Population; } \\
\text { Family } \\
\text { Expenditure } \\
\text { Survey; National } \\
\text { Income and } \\
\text { Expenditures }\end{array}$ & $\begin{array}{l}\text { EEC Social } \\
\text { Indicators for the } \\
\text { European } \\
\text { Communities } \\
1960 \text { - 1978; } \\
\text { Eurostat NIPA }\end{array}$ & \\
\hline Method & Econometric & $\begin{array}{l}\text { Econometric, } \\
\text { Descriptive }\end{array}$ & $\begin{array}{l}\text { Theoretical, } \\
\text { Econometric }\end{array}$ & Econometric \\
\hline
\end{tabular}




\section{Studies Analyzing the Inter-industry Division of Labor}

The classification efforts discussed in section 4 tried to divide services, amongst other, into producer and consumer services. Such a reclassification, even of detailed industries, will never be perfect because many 'intermediate' services also satisfy final consumer demand, and many 'consumer' services are to some extent intermediate inputs to businesses. The authors of 'Manufacturing Matters' quote the Report of the President on the Trade Agreements Program which states that $25 \%$ of US GNP originates in services used as inputs by goods-producing industries' (Cohen/ Zysman, 1987:22). The widely held assumption underlying the division into producer and consumer services seems to be that services can only be 'productive' when they contribute to the production or distribution of goods. There appears to be a certain glorification of manufacturing, which reminds us of the Physiocrats, who claimed that all wealth stems from agriculture because one cannot eat machinery. Declining employment shares do not need to go hand in hand with shrinking output, however. It may well be the case that output growth is the result of productivity growth, and that, even with growing output, employment is shrinking. Rowthorn and Wells (1987) talk of positive de-industrialization when the manufacturing sector experiences such rapid productivity growth that, despite increasing output, employment in this sector is reduced. However, this does not result in unemployment because the service sector expands sufficiently to absorb the laid-off manufacturing workers.

It is well known that the demand for agricultural products has not risen in line with productivity growth. Even though agricultural output in the industrialized countries is larger than ever before, only about 2 to $3 \%$ of the workforce are employed in agriculture. Thus, although the physiocrats were right in claiming that one cannot eat machines, they were wrong in the sense that we can live a good life without a large agricultural workforce.

The most appropriate method for disentangling the gross output of services according to their use is input-output analysis. Such analysis makes it possible to identify which share of service sector output is used as intermediate input to manufacturing, and which share is directed to final demand. Petit (1986), Greenhalgh and Gregory (2001) and Russo and Schettkat (1998) have performed input-output analyses to determine the 
inter-industry division of labor and the extent of outsourcing from the manufacturing to the services sector.

Investigating the impact of changes in final product demand (FPD) on the industry structure of employment requires an analysis of the inter-linked production structure of vertically integrated sectors (Pasinetti, 1983). Conclusions on price trends in final products derived from the analysis of productivity at the industry level may namely be very misleading if, for example, less productive activities have been outsourced from manufacturing to services (see Ten Raa/Wolff 1996). To overcome this problem, Russo and Schettkat (1998 and 2001) developed the concept of Final Product Employment (FPE), which comprises all employment - direct and intermediate - necessary for producing a final product. They also developed a measure for productivity in vertically integrated sectors, the so-called Final Product Productivity (FPP). Table 8 shows the share of products in the gross output of manufacturing and services. It can be seen that, in 1972, the US service sector provided $11.9 \%$ of the gross output of manufacturing in the form of intermediate services. By 1990 this had increased to 13.2\%. Surprisingly, Russo and Schettkat found that in the early 1970s, the amount of intermediate services in manufacturing gross output in the European countries was more or less the same as in the US, but grew faster. By 1990, Germany, France and the UK had all surpassed the US. With the exception of the UK, manufacturing inputs to services (the second column of Table 8) have been more or less stable, meaning that the division of labor between industries also seems relatively stable. 
Table 8: Percentage of Intermediate Products in Gross Output of Manufacturing and Services (constant prices)

\begin{tabular}{|l|c|c|}
\hline Year & $\begin{array}{c}\text { Services in } \\
\text { Manufacturing }\end{array}$ & $\begin{array}{c}\text { Manufacturing } \\
\text { in Services }\end{array}$ \\
\hline \multicolumn{3}{|c|}{ US } \\
\hline $\mathbf{1 9 7 2}$ & 11.91 & 7.66 \\
\hline $\mathbf{1 9 7 7}$ & 12.65 & 7.18 \\
\hline $\mathbf{1 9 9 0}$ & 13.19 & 6.85 \\
\hline \multicolumn{3}{|c|}{ GERMANY } \\
\hline $\mathbf{1 9 7 8}$ & 12.98 & 9.65 \\
\hline $\mathbf{1 9 9 0}$ & 16.73 & 8.24 \\
\hline \multicolumn{3}{|c|}{ FRANCE } \\
\hline $\mathbf{1 9 7 2}$ & 10.82 & 6.55 \\
\hline $\mathbf{1 9 7 7}$ & 11.77 & 6.54 \\
\hline $\mathbf{1 9 9 0}$ & 16.77 & 5.84 \\
\hline \multicolumn{1}{|c|}{ UNITED KINGDOM } \\
\hline $\mathbf{1 9 6 8}$ & 9.16 & 9.99 \\
\hline $\mathbf{1 9 7 9}$ & 10.22 & 16.03 \\
\hline $\mathbf{1 9 9 0}$ & 13.14 & 16.09 \\
\hline Source & Con \\
\hline
\end{tabular}

Source: Computations based on OECD Input-Output database

Services: Wholesale and Retail Trade, Restaurants and Hotels [ISIC 6];

Transport, Storage and Communication [ISIC 7];

Financial, Insurance, Real Estate, and Business Services [ISIC 8];

Community, Social and Personal Services [ISIC 9].

Manufacturing: Manufacturing [ISIC 3]

Greenhalgh and Gregory (2001) have performed a similar analysis for the UK (19791990), which seems to confirm the Russo/Schettkat conclusion that outsourcing from manufacturing to services took place, though at a modest rate. Outsourcing from services to services did increase substantially, however. Although the critical reader may doubt the validity of evidence, which is merely based on input-output data, he can rest assured, for the results derived from other data sources are very similar (see for example Freeman/Schettkat 1999).

Investigating the importance of direct (within the relevant industry), and indirect (employment in industries supplying the relevant industry), employment in various industries, Russo and Schettkat (2001) find that in manufacturing, the ratio of direct to indirect employment is somewhat higher in the US than in Germany or France (reliable detailed employment figures for the UK were not available for this study). The share of intermediate input into manufacturing, however, is lower in the US than in Germany or 
France. These results are consistent with the fact that the productivity gap between manufacturing and services is larger in the US than in Europe. In all countries, the ratio of direct to indirect employment is much higher in the service sector than in manufacturing, a result that is in line with Greenhalgh and Gregory's findings for the UK.

Table 9: Direct to Indirect Employment Ratio per Country

\begin{tabular}{|l|cc|ccc|cc|cc|}
\hline & \multicolumn{2}{|c|}{ Germany } & \multicolumn{2}{c|}{ Japan } & \multicolumn{2}{c|}{ USA } & \multicolumn{2}{c|}{ France } \\
& 1978 & 1990 & 1970 & 1990 & 1972 & 1990 & 1972 & 1990 \\
\hline \multirow{2}{*}{ Average (unweighted) } & 2.89 & 2.68 & 3.46 & 2.95 & 3.20 & 3.09 & 3.21 & 3.31 \\
& & & & & & & & \\
Industry & & & & & & & & \\
(unweighted) & 2.64 & 2.27 & 2.80 & 2.64 & 2.92 & 2.66 & 2.69 & 2.49 \\
Manufacturing & 2.65 & 2.35 & 2.93 & 2.86 & 2.39 & 2.44 & 2.62 & 2.39 \\
Services (unweighted) & 3.40 & 3.43 & 4.39 & 3.45 & 3.74 & 3.77 & 4.09 & 4.76 \\
\hline
\end{tabular}

Source: Russo/ Schettkat 2001: 148/149

Industry: Mining (ISIC 2), Manufacturing (ISIC 3), Construction (ISIC 5), Electricity, Gas, Water (ISIC 4), Manufacturing: ISIC 3;

Services: Wholesale and retail trade, restaurants and hotels (ISIC 6), Transport, Storage and Communication (ISIC 7), Financial, Insurance, Real Estate and Business Services (ISIC 8) Community, Social and Personnel Services (ISIC 9) 
Table 10: Overview of Studies Analyzing the Inter-industry Division of Labor

\begin{tabular}{|c|c|c|c|}
\hline Dimensions & & Study & \\
\hline & Petit & $\begin{array}{l}\text { Greenhalgh/ } \\
\text { Gregory }\end{array}$ & $\begin{array}{l}\text { Russo/ } \\
\text { Schettkat }\end{array}$ \\
\hline Period & $1973-1982$ & $1979-1990$ & 1969-1990 \\
\hline Countries & $\begin{array}{l}\text { Belgium, Federal } \\
\text { Republic of Germany, } \\
\text { France, Italy, NL, UK, } \\
\text { US }\end{array}$ & UK & $\begin{array}{l}\text { France, Germany, } \\
\text { Japan, NL, UK, US }\end{array}$ \\
\hline Employment & & Rising & $\begin{array}{l}\text { Employment share of } \\
\text { manufacturing declines } \\
\text { because of a shift in } \\
\text { final demand and } \\
\text { unbalanced } \\
\text { productivity growth }\end{array}$ \\
\hline Final Demand & $\begin{array}{l}30-35 \% \text { of total } \\
\text { output is accounted for } \\
\text { by household services, } \\
15-20 \% \text { by } \\
\text { integrating services; } \\
5 \text { to } 10 \% \text { by various } \\
\text { services; almost } 10 \% \\
\text { by health and education }\end{array}$ & $\begin{array}{l}\text { Rising, predominantly } \\
\text { in financial services }\end{array}$ & $\begin{array}{l}\text { According to the Final } \\
\text { Product approach, final } \\
\text { demand shifted from } \\
\text { manufacturing to } \\
\text { services and was driven } \\
\text { by final consumption }\end{array}$ \\
\hline $\begin{array}{l}\text { Private Consumption/ } \\
\text { Household expenditure }\end{array}$ & $\begin{array}{l}\text { Demand for household } \\
\text { services accounts for } \\
\text { between } 30-35 \% \text { of } \\
\text { total output }\end{array}$ & & \\
\hline $\begin{array}{l}\text { Government } \\
\text { Consumption }\end{array}$ & $\begin{array}{l}\text { Expenditures on health } \\
\text { and education account } \\
\text { for } 10 \% \text { of total output }\end{array}$ & & \\
\hline Investment & & & \\
\hline
\end{tabular}




\begin{tabular}{|c|c|c|c|}
\hline Imports/Exports & $\begin{array}{l}\text { Exports account on } \\
\text { average for only } 10 \% \\
\text { of total service use }\end{array}$ & & \\
\hline Industry Productivity & & $\begin{array}{l}\text { Services were matching } \\
\text { or exceeding } \\
\text { manufacturing in } \\
\text { productivity, but large } \\
\text { differences exist } \\
\text { between industries } \\
\text { within the service } \\
\text { sector }\end{array}$ & \\
\hline $\begin{array}{l}\text { Inter-industry } \\
\text { division of labor }\end{array}$ & $\begin{array}{l}\text { In } 1975 \text {, externalization } \\
\text { accounted for } \pm 4 \% \text { of } \\
\text { value added in } \\
\text { manufacturing }\end{array}$ & $\begin{array}{l}\text { Increasing but within } \\
\text { services not between } \\
\text { manufacturing and } \\
\text { services }\end{array}$ & $\begin{array}{l}\text { Increased, though not } \\
\text { substantially. } \\
\text { Greater specialization } \\
\text { in the US cannot be } \\
\text { confirmed by the data }\end{array}$ \\
\hline Summary & $\begin{array}{l}\text { Some trends: 1) service } \\
\text { economy more } \\
\text { developed in US than } \\
\text { in European countries; } \\
\text { 2) similar rate of } \\
\text { growth in trade in } \\
\text { goods and services, but } \\
\text { services have smaller } \\
\text { share in total exports; } \\
\text { 3) 1970-1975 => } \\
\text { expenditure on comm. } \\
\text { \& transport remained } \\
\text { stable, but increased on } \\
\text { financial } \\
\text { intermediation; } \\
\text { 4) externalization of } \\
\text { tertiary functions is less } \\
\text { important than often } \\
\text { assumed; } \\
\text { 5) stability in service } \\
\text { sector employment } \\
\text { during expansion and } \\
\text { recession; }\end{array}$ & $\begin{array}{l}\text { From the early 1980s } \\
\text { onwards, the service } \\
\text { sector has been a major } \\
\text { force behind output and } \\
\text { employment creation, } \\
\text { in particular because of } \\
\text { growing demand for } \\
\text { services as intermediate } \\
\text { products. }\end{array}$ & $\begin{array}{l}\text { Six trends: } \\
\text { 1)final demand shift } \\
\text { from manufacturing to } \\
\text { services; } \\
\text { 2) share of } \\
\text { manufacturing declines } \\
\text { in employment; } \\
\text { 3) less so in real } \\
\text { output; } \\
\text { 4) share of intermediate } \\
\text { services in } \\
\text { manufacturing gross } \\
\text { output is } \\
\text { US < Germany; } \\
\text { 5) goods from service } \\
\text { industries in } \\
\text { manufacturing gross } \\
\text { output changed little; } \\
\text { 6) productivity gains } \\
\text { mainly result from } \\
\text { productivity } \\
\text { improvements within } \\
\text { industries }\end{array}$ \\
\hline Data & $\begin{array}{l}\text { SOEC Balance of } \\
\text { Payments data; SOEC } \\
\text { Structural Databank; } \\
\text { Input-Output data from } \\
\text { Eurostat and Survey of } \\
\text { Current Business }\end{array}$ & $\begin{array}{l}\text { British input-output } \\
\text { data }\end{array}$ & $\begin{array}{l}\text { OECD } \\
\text { Input-Output data; } \\
\text { OECD ISDB; NIPA }\end{array}$ \\
\hline Method & $\begin{array}{l}\text { Econometric, } \\
\text { Input-output }\end{array}$ & Input-output & $\begin{array}{l}\text { Econometric, } \\
\text { Input-output }\end{array}$ \\
\hline
\end{tabular}




\section{Studies Analyzing Productivity Differences}

All 'cost-disease' arguments center on the gap in productivity level, or growth rate, between the service sector and manufacturing. Price trends in many, though not in all, service industries support this view (see Baumol 2001). Fuchs (1968) already pointed out that the rising share of services in overall demand at current prices may overestimate the relative expansion of services, while the deflated figures (the share of services in real demand) are likely to give an underestimation. In the 1990s, the Consumer Price Index (CPI) became the subject of heavy debates in the U.S.. The socalled 'Boskin commission' argued that many goods - such as VCRs, microwave ovens and personal computers - enter the CPI too late, that is, after they have penetrated the market and their price has fallen by 80\% (Boskin et al., 1998: 10). According to the Boskin commission, this practice leads to an overstatement of prices that raises the CPI by $0.6 \%$-point per year. Such an overestimation of price trends would, in turn, result in an underestimation of real output growth. Service industries may similarly be suffering from an underestimation of their output, and thus from an overestimation of their price trends and an underestimation of their productivity growth. Although estimates of manufactured output are also problematic, measurement problems tend to be more severe in services (Griliches 1992:6).

But is there an actual difference in measurement bias between goods and service production, as Fuchs suggests? Zvi Griliches (1992:3) has pointed out that a stronger downward bias in service-output measurement, that is an overstatement of service prices, may be the cause of the possible underestimation of productivity growth in services. 'Because of this lack of data, a number of service industries series are deflated by makeshift deflators, and real output is assumed to grow proportionally to some measure of input and to lead to no observed productivity growth by assumption. The latter is true for the whole government sector, the contribution of various nonprofit organizations, such as universities, and such difficult-to-measure sectors as banking and business services' (Griliches 1992:6/7). Griliches also mentions, however, that in some service industries, such as communication, output is relatively more homogenous than in many goods-producing industries and that, consequently, measurement problems in those service industries are less severe (Griliches, 1992:7). In other words, 
it remains unclear whether the measurement bias is stronger for the overall service sector than for goods.

Using NIPA data, Griliches (1992) finds slightly higher productivity levels in services than in commodity production for 1948, but a decline in relative service productivity levels in the 1960s and again in the 1980s. The only exception is trade, which also lagged behind in productivity growth (Griliches 1992:3). 'In fact, it was only relatively recently that the average GNP per hour in all the service sectors fell below that of commodity production. But productivity growth was indeed slower in the fastest growing subsectors: retail trade, FIRE (finance, insurance, real estate), and services, a fact that contributed to the overall decline in the relative performance of services as a whole. Because these are also the industries where output measurement may be most difficult, the suspicion is raised that some of the observed declines could be spuriousthe result of our inability to observe and interpret the historical developments correctly' (Griliches 1992: 3,4).

Productivity trends in trade seem particularly prone to fall behind those of manufacturing. Quality changes may be part of the explanation. Longer opening hours of shops, for example, may increase the convenience for shoppers but lead to a decline in measured productivity. Measuring retail trade output (and productivity) in terms of physical quantities, such as the number of oranges sold, would neglect the contribution that the arrangement of goods makes to the convenience of the consumer. Shopping in a shop where the goods have been arranged nicely may be more pleasant than shopping at a discount supermarket, but such differences will be ignored by pure 'quantity measures' (Griliches, 1992). Moreover, in trade, the boundaries between manufacturers, wholesalers, retailers and consumer has shifted so that a larger share of the consumer's time is integrated in the process.

The view that measurement errors are not a substantial source of the productivity growth slowdown (Gordon/ Baily 1988) was corrected by Gordon (1996), who emphasizes that there are major problems with the output measurement of 'miscellaneous services', which, in 1991, represented 22\% of the US market. Its largest subsector, 'health', tends to suffer from notorious measurement problems. Gordon identifies major productivity growth problems in utilities, finance and real estate, as 
well as in miscellaneous services. However, productivity growth exhibits no productivity slowdown if the period 1960-73 is compared to the period 1979-1992.

The McKinsey Global Institute (1992) takes a different approach to productivity comparisons and chooses to use information from local McKinsey experts. Their international comparison titled 'Service Sector Productivity' thus provides a 'bottomup' measure of international differences in productivity in service industries (see Table 11)

Table 11: Estimates of Labor Productivity (US=100)

\begin{tabular}{|l|c|c|c|c|c|}
\hline & Market GDP & Telecom & $\begin{array}{c}\text { Retail } \\
\text { Banking }\end{array}$ & $\begin{array}{c}\text { General } \\
\text { merchandise } \\
\text { retailing }\end{array}$ & Restaurants \\
\hline Germany & 80 & 52 & 68 & 96 & 92 \\
France & 84 & 62 &. & 69 & 104 \\
UK & 72 & 54 & 64 & 82 &. \\
\hline
\end{tabular}

Source: McKinsey Global Institute (1992)

According to the McKinsey estimates, in 1989, labor productivity in the US retail banking industry was $32 \%$-points higher than in its German counterpart, and 36\%points higher than in the UK (US = 100). The much wider use of IT in US industry may be one of the major factors explaining this difference in productivity, in particular through its impact on the organization of labor. In the last decade, industry managers in the US were increasingly confronted with intense competitive pressures, which encouraged higher productivity. In the UK, in contrast, managers have only recently been confronted with such pressures, which are expected, however, to have a profound impact on the UK industry. In Germany, high customer loyalty and high non-regulatory barriers to entry have long sheltered the industry from competitive pressures. This has prevented German managers from improving productivity and from building an industry structure that would serve customers as productively and efficiently as possible ${ }^{9}$.

\footnotetext{
${ }^{9}$ However, seeing the common use of cheques in the US, together with its back-and-forth mailing, McKinsey's findings will come as a surprise for Europeans.
} 
As the McKinsey study points out, in retailing, income effects are important. As income rises, an increasing share of income will be spent on luxury goods and fashion, instead of on basic goods, such as groceries and purely functional semi-durables and durables. A wider income distribution thus seems to favor the sale of luxury goods in a luxurious environment, in which value-added and productivity are higher (McKinsey Global Institute, 1992). 'Category-killer retailers' may operate in markets in which products have become more or less standardized, and in which information about products has sufficiently penetrated the market to allow price competition to dominate (Schettkat, 2002). Examples are 'Toys R Us' and 'Circuit City', two toy stores that have more or less restricted their function to the distribution of their products (McKinsey Global Institute, 1992). Regulations on shopping hours, shopping days and the number of sales events are competition-reducing measures that lower customer service. They may be an important explanation for the enormous difference in retail employment across countries

However, the frequently heard claims that service productivity is lower in the US than in Europe, and that lack of efficiency, or a more severe 'cost disease' explains the high share of US employment in services, are not confirmed by the McKinsey study or by other internationally comparative figures. 
Table 12: Overview of Studies Analyzing Productivity Differences

\begin{tabular}{|c|c|c|c|c|c|}
\hline Dimension & \multicolumn{5}{|c|}{ Study } \\
\hline & $\begin{array}{l}\text { McKinsey } \\
\text { Global Instit. }\end{array}$ & $\begin{array}{l}\text { Baumol/ } \\
\text { Blackm/Wolff }\end{array}$ & Griliches & $\begin{array}{l}\text { Rowthorn/ } \\
\text { Ramaswamy }\end{array}$ & Gordon \\
\hline Period & 1988-1991 & $1947-1976$ & 1948-1989 & $1963-1994$ & $1960-1992$ \\
\hline Countries & $\begin{array}{l}\text { France, } \\
\text { Germany, } \\
\text { Japan, UK, US }\end{array}$ & US & US & $\begin{array}{l}\text { Austr, Aus., } \\
\text { Belg., Can., } \\
\text { Denm., Fin., } \\
\text { Fr., Germ., } \\
\text { Gr., It., Jap., } \\
\text { NL, N-Z, } \\
\text { Norw., Sp., } \\
\text { Swe., UK, US }\end{array}$ & $\begin{array}{l}\text { Australia, } \\
\text { Canada, } \\
\text { France, } \\
\text { Germany, } \\
\text { Italy, Japan, } \\
\text { UK, US }\end{array}$ \\
\hline Employment & Rising & $\begin{array}{l}\text { Rising, } \\
\text { because of low } \\
\text { productivity } \\
\text { growth in so- } \\
\text { called stagnant } \\
\text { service } \\
\text { industries. }\end{array}$ & $\begin{array}{l}\text { Rising } \\
\text { probably } \\
\text { because of } \\
\text { rising demand } \\
\text { for services }\end{array}$ & & \\
\hline $\begin{array}{l}\text { Final } \\
\text { Demand }\end{array}$ & & $\begin{array}{l}\text { Constant share } \\
\text { of services in } \\
\text { real output. } \\
\text { No } \\
\text { relationship } \\
\text { between } \\
\text { prosperity and } \\
\text { the real level } \\
\text { of output of } \\
\text { services. }\end{array}$ & & $\begin{array}{l}\text { Income } \\
\text { elasticity of } \\
\text { demand for } \\
\text { manufactures } \\
\text { is well above } \\
\text { unity when a } \\
\text { country is } \\
\text { poor, and falls } \\
\text { below unity } \\
\text { when it } \\
\text { matures }\end{array}$ & \\
\hline $\begin{array}{l}\text { Private } \\
\text { consumption/ } \\
\text { Household } \\
\text { expenditure }\end{array}$ & & & & & \\
\hline $\begin{array}{l}\text { Government } \\
\text { Consumption }\end{array}$ & & & & & \\
\hline Investment & & & & $\begin{array}{l}1 / 6^{\text {th }} \text { of dein- } \\
\text { dustrialization } \\
\text { is fall invest./ }\end{array}$ & \\
\hline
\end{tabular}




\begin{tabular}{|c|c|c|c|c|c|}
\hline & & & & GDP ratio & \\
\hline $\begin{array}{l}\text { Imports/ } \\
\text { Exports }\end{array}$ & $\begin{array}{l}\text { Share of } \\
\text { services in US } \\
\text { exports rose } \\
\text { from } 15 \% \text { to } \\
26 \% \text { between } \\
1976-1990 \\
\end{array}$ & & & & \\
\hline $\begin{array}{l}\text { Industry } \\
\text { productivity }\end{array}$ & $\begin{array}{l}\text { Service sector } \\
\text { productivity } \\
\text { differences } \\
\text { between } \\
\text { countries are } \\
\text { due to the } \\
\text { organization } \\
\text { of labor, } \\
\text { which depends } \\
\text { on competitive } \\
\text { intensity and } \\
\text { economic } \\
\text { policies }\end{array}$ & & $\begin{array}{l}\text { There is no } \\
\text { productivity } \\
\text { gap between } \\
\text { services as a } \\
\text { whole and } \\
\text { manufacturing } \\
\text { Services that } \\
\text { fell behind } \\
\text { suffered from } \\
\text { service output } \\
\text { measurement } \\
\text { problems }\end{array}$ & & $\begin{array}{l}\text { CPI bias has } \\
\text { led to under- } \\
\text { statement of } \\
\text { US } \\
\text { productivity } \\
\text { growth in } \\
\text { manufacturing } \\
\text { retail trade and } \\
\text { some services. } \\
\text { In utilities and } \\
\text { air transport, } \\
\text { the slowdown } \\
\text { is real }\end{array}$ \\
\hline $\begin{array}{l}\text { Inter- } \\
\text { industry } \\
\text { division of } \\
\text { labor }\end{array}$ & $\begin{array}{l}23 \% \text { of value } \\
\text { of US } \\
\text { industrial sales } \\
\text { reflect service } \\
\text { sector inputs } \\
\text { (1987) }\end{array}$ & & & & \\
\hline Summary & $\begin{array}{l}\text { Higher US } \\
\text { service sector } \\
\text { productivity is } \\
\text { mainly due to } \\
\text { management } \\
\text { behavior. } \\
\text { Government } \\
\text { ownership and } \\
\text { demand } \\
\text { factors are } \\
\text { also important. } \\
\text { Differences in } \\
\text { output mix, } \\
\text { economies of } \\
\text { scale, intensity } \\
\text { of capital } \\
\text { used, and skill } \\
\text { of non- } \\
\text { managerial } \\
\text { labor have } \\
\text { little or no } \\
\text { explanatory } \\
\text { power }\end{array}$ & $\begin{array}{l}\text { Idea that } \\
\text { deindustriali- } \\
\text { zation of the } \\
\text { US is due to } \\
\text { decline in } \\
\text { productivity, } \\
\text { is unfounded } \\
\text { because shift } \\
\text { to services } \\
\text { occurs in all } \\
\text { advanced } \\
\text { economies. } \\
\text { Shift in } \\
\text { demand to } \\
\text { services is } \\
\text { illusion and } \\
\text { due to the fact } \\
\text { that nominal } \\
\text { and } \\
\text { employment } \\
\text { figures rising } \\
\text { by the 'cost- } \\
\text { disease' }\end{array}$ & $\begin{array}{l}\text { Technological } \\
\text { stagnancy of } \\
\text { some services } \\
\text { may be } \\
\text { spurious, due } \\
\text { to } \\
\text { measurement } \\
\text { error }\end{array}$ & $\begin{array}{l}\text { Deinustrializa- } \\
\text { tion is mainly } \\
\text { due to internal } \\
\text { factors - that } \\
\text { is, interactions } \\
\text { among shifts } \\
\text { of demand, } \\
\text { faster prod. } \\
\text { growth in } \\
\text { manufactures } \\
\text { than services, } \\
\text { and the } \\
\text { associated fall } \\
\text { in the relative } \\
\text { price of } \\
\text { manufactures). } \\
\text { North-south } \\
\text { trade explains } \\
\text { only } 1 / 5^{\text {th }} \text { of } \\
\text { decline in } \\
\text { manufacturing } \\
\text { employment }\end{array}$ & $\begin{array}{l}\text { CPI bias can } \\
\text { help to explain } \\
\text { part of the } \\
\text { productivity } \\
\text { growth } \\
\text { slowdown in } \\
\text { the US. } \\
\text { Looking at } \\
\text { prod. } \\
\text { differences } \\
\text { across } \\
\text { countries, it } \\
\text { can be } \\
\text { concluded that } \\
\text { the US has } \\
\text { been } \\
\text { performing } \\
\text { poorly except } \\
\text { in agriculture } \\
\text { and mining } \\
\text { and telecom }\end{array}$ \\
\hline Data & $\begin{array}{l}\text { BEA; OECD; } \\
\text { US Dept. of } \\
\text { Commerce; } \\
\text { Statistiche } \\
\text { Bundesamt; } \\
\text { INSEE; } \\
\text { Survey of } \\
\text { Current } \\
\text { Business }\end{array}$ & NIPA & NIPA & $\begin{array}{l}\text { NIPA; OECD } \\
\text { Historical } \\
\text { Statistics; } \\
\text { UNCTAD } \\
\text { database; } \\
\text { ISDB }\end{array}$ & NIPA; BLS \\
\hline Method & $\begin{array}{l}\text { Micro, using } \\
\text { local experts }\end{array}$ & Econometric & $\begin{array}{l}\text { Econometric, } \\
\text { Theoretical }\end{array}$ & $\begin{array}{l}\text { Econometric } \\
\text { analysis }\end{array}$ & Theoretical \\
\hline
\end{tabular}




\section{Concluding Summary}

Each of the studies discussed above covers one or more aspects of the complex mix of supply and demand factors influencing the rise of service sector employment in advanced industrialized countries.

A first group of studies attempts to regroup service industries into smaller sub-groups in order to analyze changes in employment structure. Most of these studies - for example, Castells (1996) and Elfring (1988) - follow Singelmann's reclassification (Singelmann, 1978), which divides the service sector into producer, distributive, personal and social services. Scharpf (1996), however, develops his own classification based on pre-existing ISIC categories. Some studies, such as Castells (1996) and Albin and Appelbaum (1990) choose to analyze the changing structure of employment by distinguishing services on the basis of their information and knowledge content.

The work of Clark (1940) and Fisher (1935), who both made a classic contribution to the 'shift to services debate', belong to a second group of studies, which focus on demand-side explanations of the shift to services. In their opinion, changes in the structure of final demand are the major cause of the rise of employment in services. The works of Fuchs (1968), Gershuny (1978) and Gershuny/Miles (1983), on the US and the UK respectively, also pay attention to developments in the household demand for services, but do not support the view that the final demand for services is increasing.

A third group of studies tries to explain the rising share of service employment in terms of changes in the inter-industry division of labor. Using input-output tables, the studies of Greenhalgh and Gregory (2001), Russo and Schettkat (1998, 2001) and Petit (1986), show that outsourcing from manufacturing to services has increased, but that this increase is insufficient to explain the trend to service employment. The 'outsourcing' argument fails as an explanation for the differences in the share of service industry employment between the US and Europe. 
A last group of studies follows Baumol (1967, 2001), who is one of the strongest and best-known antagonists of the demand-side explanation for the shift to services. In Baumol's opinion, supply-side factors, that is productivity differentials between the manufacturing and the service sector, explain why the share of employment in services is growing. This so-called 'cost-disease' hypothesis rests on the assumption that the share of goods and services in real output is constant over time. Fuchs' (1968) comprehensive analysis provides evidence for the Baumol hypothesis, and finds that service sector growth is mainly determined by the intermediate demand for services. Esping-Andersen (1993) also takes a 'cost-disease' approach, but his book is an argument about the impact of welfare state institutions, rather than an empirical analysis. Baumol's cost disease hypothesis implies stronger price rises in services than in manufacturing, which is confirmed for some, but not for all services. Furthermore, it remains unclear, to what extent the prices of services are more strongly biased than those of goods are.

The analytical dimensions covered by the various studies are summarized in Table 13. As the pattern in Table 13 clearly shows, except for Fuchs' seminal 1968 study, each of the studies covered in this paper focuses only on a few aspects of the rising share of service employment and some selected additional indicators, without attempting to draw the full picture. And although Fuchs' work is analytically comprehensive, his analysis is restricted to the US and only covers the period up till the 1960s, basically leaving us without any comprehensive studies analyzing the expansion of service employment from Fuchs to the present. 
Table 13: Overview of Major Analytical Dimensions Covered by Service Sector Studies

\begin{tabular}{|c|c|c|c|c|c|c|c|c|c|c|c|c|c|c|c|c|c|c|c|c|c|c|c|c|c|}
\hline \multirow[t]{3}{*}{ Dimension } & \multicolumn{25}{|c|}{ The Studies } \\
\hline & \multicolumn{5}{|c|}{ The Classics } & \multicolumn{7}{|c|}{ Employment Structure } & \multicolumn{4}{|c|}{ Final Demand } & \multicolumn{5}{|c|}{ Inter-Ind. Division of Labor } & \multicolumn{4}{|c|}{ Product. Differences } \\
\hline & 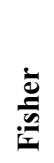 & Uَ & 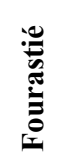 & $\overline{\mathscr{O}}$ & $\frac{n}{\varrho}$ & $\stackrel{\stackrel{00}{\Xi}}{\stackrel{B}{\Xi}}$ & 产 & 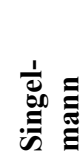 & 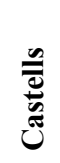 & 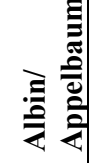 & 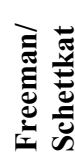 & $\stackrel{\vec{D}}{\mathscr{D}}$ & 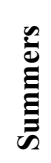 & 吾 & 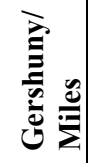 & 党 & 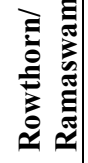 & 苛 & 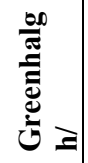 & 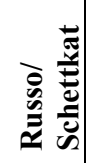 & 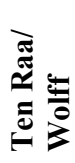 & 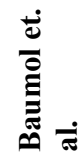 & تేّ & 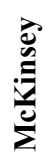 & 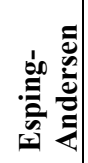 \\
\hline Employm. & $\mathrm{X}$ & $\mathrm{X}$ & $\mathrm{X}$ & $\mathrm{X}$ & $\mathrm{X}$ & $\mathrm{X}$ & $\mathrm{X}$ & $\mathrm{X}$ & $\mathrm{X}$ & $\mathrm{X}$ & $\mathrm{X}$ & $\mathrm{X}$ & & & $\mathrm{X}$ & $\mathrm{X}$ & & & $\mathrm{X}$ & $\mathrm{X}$ & & & & & $\mathrm{X}$ \\
\hline Final dem. & $\mathrm{X}$ & $\mathrm{X}$ & $\mathrm{X}$ & $\mathrm{X}$ & $\mathrm{X}$ & $\mathrm{X}$ & & $\mathrm{X}$ & & & & & $\mathrm{X}$ & $\mathrm{X}$ & $\mathrm{X}$ & $\mathrm{X}$ & $\mathrm{X}$ & $\mathrm{X}$ & $\mathrm{X}$ & $\mathrm{X}$ & & & & & \\
\hline $\begin{array}{l}\text { Private } \\
\text { consump. }\end{array}$ & $\mathrm{X}$ & $\mathrm{X}$ & $\mathrm{X}$ & & $\mathrm{X}$ & $\mathrm{X}$ & & & & & $\mathrm{X}$ & & $\mathrm{X}$ & $\mathrm{X}$ & $\mathrm{X}$ & & & $\mathrm{X}$ & & & & & & & \\
\hline $\begin{array}{l}\text { Household } \\
\text { Expend. }\end{array}$ & & $\mathrm{X}$ & & & $\mathrm{X}$ & & & & & & & & & $\mathrm{X}$ & & & & & & & & & & & \\
\hline $\begin{array}{l}\text { Household } \\
\text { Structure }\end{array}$ & & & & & $\mathrm{X}$ & & & & & & & & & & & & & & & & & & & & \\
\hline $\begin{array}{l}\text { Lab. Force } \\
\text { Participat. }\end{array}$ & & & & & & & & & & & & & & & & & & & & & & & & & \\
\hline $\begin{array}{l}\text { Governm. } \\
\text { Consumpt. }\end{array}$ & & & & & $\mathrm{X}$ & $\mathrm{X}$ & & & & & & & & $\mathrm{X}$ & & & & $\mathrm{X}$ & & & & & & & $\mathrm{X}$ \\
\hline Investment & & & & & & & & & & & & & & & & & $\mathrm{X}$ & & & & & & & & \\
\hline $\begin{array}{l}\text { Imports/ } \\
\text { Exports }\end{array}$ & & & & & & & & & & & & & & & & $\mathrm{X}$ & $\mathrm{X}$ & $\mathrm{X}$ & & & & & & & \\
\hline $\begin{array}{l}\text { Industry } \\
\text { Product. }\end{array}$ & & & $\mathrm{X}$ & $\mathrm{X}$ & $\mathrm{X}$ & $\mathrm{X}$ & & & & & & & & $\mathrm{X}$ & $\mathrm{X}$ & & $\mathrm{X}$ & $\mathrm{X}$ & $\mathrm{X}$ & $\mathrm{X}$ & & & & & \\
\hline Skills & & & & & $\mathrm{X}$ & & & & & & & & & & & & & & & & & & & & \\
\hline $\begin{array}{l}\text { Capital/ } \\
\text { Labor }\end{array}$ & & & & & & & & & & & & & & & & & & & & & & & & & \\
\hline Hours & & & & & $\mathrm{X}$ & & & & & & & & & & & & & & & & & & & & \\
\hline $\begin{array}{l}\text { Inter-ind. } \\
\text { div. of lab. }\end{array}$ & & & & & $\mathrm{X}$ & & & & & & & & & $\mathrm{X}$ & $\mathrm{X}$ & & & $\mathrm{X}$ & $\mathrm{X}$ & $\mathrm{X}$ & & & & & \\
\hline $\begin{array}{l}\mathrm{I}-\mathrm{O} \\
\text { structure }\end{array}$ & & & & & & & & & & & & & & & & & & & & $\mathrm{X}$ & & & & & \\
\hline $\begin{array}{l}\text { Vert. integr } \\
\text { sectors }\end{array}$ & & & & & $\mathrm{X}$ & & & & & & & & & & & & & & & $\mathrm{X}$ & & & & & \\
\hline
\end{tabular}




\section{Bibliography}

Albin, P. and Appelbaum, E. (1990) 'Differential Characteristics of Employment Growth in Services'. In: Appelbaum, E./Schettkat, R. (eds.) Labor Market Adjustments to Structural Change and Technological Progress. New York: Praeger Publishers. pp. $36-53$.

Appelbaum, E. and Schettkat, R. (1999) 'Are Prices Unimportant? The Changing Structure of the Industrialized Economies'. In: Journal of Post Keynesian Economics, Volume 21, No. 3, pp. 387-398. Reprinted in: Ten Raa, T./ Schettkat, R. (eds.) The Growth of Service Industries: The Paradox of Exploding Costs and Persistent Demand. Cheltenham: Edward Elgar. pp. 121-131.

Baumol, W. J. (2001) 'Paradox of the Services: Exploding Costs, Persistent Demand'. In: Ten Raa, T./ Schettkat, R. (eds.) The Growth of Service Industries: The Paradox of Exploding Costs and Persistent Demand. Cheltenham: Edward Elgar. pp. 3 - 28

Baumol, W.J., Blackman, S.A.B., Wolff, E.N. (1992) Productivity and American Leadership: The Long View. Cambridge (Massachusetts) and London: The MIT Press.

Baumol, W. J. (1967) 'Macroeconomics of Unbalanced Growth: the Anatomy of Urban Crisis'. In: American Economic Review, Vol. 57, pp. 415 - 426.

Baumol, W.J. and Bowen, W.G. (1966) Performing Arts: The Economic Dilemma. New York: Twentieth Century Fund.

Boskin, M.J., Dulberger, E.R., Gordon, R.J., Griliches, Z. and Jorgenson, D.W. (1998) 'Consumer Prices, the Consumer Price Index, and the Cost of Living'. In: The Journal of Economic Perspectives, Vol. 12, no. 1, pp. 3-27.

Castells, M. (1996) The Rise of the Network Society. Malden (Mass.) and Oxford: Blackwell Publishers. pp. 201-326

Clark, C. (1940, revised and reprinted in 1951) The Conditions of Economic Progress. London: MacMillan \& Co. Ltd.

Cohen, S.S., Zysman, J. (1987) Manufacturing Matters. The Myth of the Post-industrial Economy. New York: Basic Books Inc.

Curtis, D.C.A. and Murthy, K.S.R. (1998) 'Economic Growth and Restructuring: A Test of Unbalanced Growth Models - 1977-1992'. In: Applied Economic Letters, no. 5, pp. 777-780.

Elfring, T. (1988) Service Employment in Advanced Economies. A Comparative Analysis of Its Implications for Economic Growth. Groningen: Rijksuniversiteit Groningen. 
Elfring, T. (1989) 'New Evidence on the Expansion of Service Employment in Advanced Economies'. In: Review of Income and Wealth, Series 35, No. 4.

Esping-Andersen, G. (1999) Social Foundations of Postindustrial Economies. Oxford: OUP

Fisher, A.G.B. (1935) The Clash of Progress and Security. London: MacMillan \& Co. Ltd.

Fourastié, J. (1949) Le Grand Espoir du XXe Siècle. Paris: Presses Universitaires de France. Reprinted as 'Moderne Techniek en Economische Ontwikkeling' (1965). Amsterdam: Het Spectrum.

Freeman, R.B., Schettkat, R. (1999) Differentials in Service Industry Employment Growth: Germany and the US in the comparable German American Structural Database. Brussels: European Commission.

Freeman, R.B., Schettkat, R. (2002) 'Marketization of Production and the US-Europe Employment Gap'. NBER Working Paper no. 8797. Cambridge (Mass.): National Bureau of Economic Research.

Fuchs, V.R. (1968) The Service Economy. New York and London: Colombia University Press.

Gershuny, J. (1978) After Industrial Society? The Ermerging Self-service Economy. London and Basingstoke: MacMillan \& Co. Ltd.

Gershuny, J., Miles, I. (1983) The New Service Economy. The Transformation of Employment in Industrial Societies. London: Frances Pinter.

Gordon, R. J. (1996) 'Problems with the Measurement and Performance of Service Sector Productivity in the United States'. NBER Working Paper no. 5519, pp. $139-166$

Gregory, M., Greenhalgh, C. (2001) Structural Change and the Emergence of the New Service Economy. Paper prepared for the Leverhulme Programme Final Conference 'The Labour Market Consequences'.

Griliches, Z. ed. (1992) Output Measurement in the Service Sectors. Chicago and London: University of Chicago Press.

Katouzian, M.A. (1970) 'The Development of the Service Sector: A New Approach'. In: Oxford Economic Papers, pp. 362 - 382.

Machlup, F. (1962) The Production and Distribution of Knowledge in the United States. Princeton: Princeton University Press. 
McKinsey Global Institute (1992) Service Sector Productivity. Washington: McKinsey Global Institute.

OECD (2000) Employment Outlook. Paris: OECD

Pasinetti, L. (1983) Structural Change and Economic Growth: An Essay in the Dynamics of Wealth of Nations. Cambridge: CUP.

Petit, P. (1986) Slow Growth and the Service Economy. London: Frances Pinter.

Porat, M.U. (1977) The Information Economy: Definition and Measurement. U.S. Department of Commerce, Office of Telecommunications. Washington D.C., U.S. Government Printing Office.

Rowthorn, R. and Ramaswamy, R. (1999) 'Growth, Trade and Deindustrialization'. In: IMF Staff Papers, vol. 46, no. 1., pp. 18- 41.

Rowthorn, R. and Wells, J.R. (1987) De-industrialization and Foreign Trade. Cambridge: CUP.

Russo, G. and Schettkat, R. (1999) 'Are Structural Economic Dynamics a Myth? Changing Industrial Structure in the Final Product Concept'. In: Economia \& Lavoro, No. 3-4, pp. 173-188.

Russo, G. and Schettkat, R. (2001) 'Structural economic dynamics: myth or reality? Structural change and the final product concept'. In: Ten Raa, T./ Schettkat, R. (eds.) The Growth of Service Industries: The Paradox of Exploding Costs and Persistent Demand, Cheltenham: Edward Elgar. pp. 132-166.

Scharpf, F. W. (1990) 'Structures of Postindustrial Society or Does Mass Unemployment Disappear in the Service and Information Economy?' In: Appelbaum, E./Schettkat, R. (eds.) Labor Market Adjustments to Structural Change and Technological Progress. New York: Praeger Publishers. pp. 17-36.

Schettkat, R. (2002) The Two Blades of the Scissors: The Interaction Between Demand and Supply in Market Economies. (Manuscript).

Singelmann, J. (1978) From Agriculture to Services. The Transformation of Industrial Employment. Beverly Hills: Sage Publications.

Skolka, J. (1976) 'Long-term Effects of Unbalanced Labour Productivity Growth; On the Way to a Self-service Society'. In: Solari, L. and Du Pasquier, J-N. (eds.) Private and Enlarged Consumption: Essays in Methodology and Empirical Analysis.

Amsterdam, New York, Oxford: North Holland Publishing Company. pp. 279 - 301. 
Storrie, D. (2001) 'Service Employment, Productivity and Growth'. In: Anxo, D. and Storrie, D. (eds) The Job Creation Potential of the Service Sector in Europe. Luxembourg: Office for Official Publications of the European Communities. pp. $35-65$

Summers, R. (1985) 'Services in the International Economy'. In: Inman, R.P (ed.) Managing the Service Economy. Cambridge: CUP. pp. 27 - 48.

Ten Raa, T. and Wolff, E.N. (1996) Outsourcing of Services and the Productivity Recovery in US Manufacturing in the 1980s. Tilburg University, CENTER Discussion Paper no. 9689. 


\section{IZA Discussion Papers}

\begin{tabular}{|c|c|c|c|c|}
\hline No. & Author(s) & Title & Area & Date \\
\hline 949 & C. J. Flinn & $\begin{array}{l}\text { Minimum Wage Effects on Labor Market } \\
\text { Outcomes under Search with Bargaining }\end{array}$ & 6 & $12 / 03$ \\
\hline 950 & $\begin{array}{l}\text { P. Garibaldi } \\
\text { E. Wasmer }\end{array}$ & $\begin{array}{l}\text { Equilibrium Employment in a Model of Imperfect } \\
\text { Labor Markets }\end{array}$ & 1 & $12 / 03$ \\
\hline 951 & $\begin{array}{l}\text { P. Garibaldi } \\
\text { E. Wasmer }\end{array}$ & $\begin{array}{l}\text { Raising Female Employment: Reflexions and } \\
\text { Policy Tools }\end{array}$ & 5 & $12 / 03$ \\
\hline 952 & $\begin{array}{l}\text { O. Raaum } \\
\text { K. G. Salvanes } \\
\text { E. Ø. Sørensen }\end{array}$ & The Neighbourhood Is Not What It Used to Be & 3 & $12 / 03$ \\
\hline 953 & $\begin{array}{l}\text { O. Raaum } \\
\text { K. G. Salvanes } \\
\text { E. Ø. Sørensen }\end{array}$ & $\begin{array}{l}\text { The Impact of a Primary School Reform on } \\
\text { Educational Stratification: A Norwegian Study of } \\
\text { Neighbour and School Mate Correlations }\end{array}$ & 5 & $12 / 03$ \\
\hline 954 & $\begin{array}{l}\text { P. Portugal } \\
\text { J. T. Addison }\end{array}$ & Six Ways to Leave Unemployment & 6 & $12 / 03$ \\
\hline 955 & V. Grossmann & $\begin{array}{l}\text { Risky Human Capital Investment, Income } \\
\text { Distribution, and Macroeconomic Dynamics }\end{array}$ & 5 & $12 / 03$ \\
\hline 956 & $\begin{array}{l}\text { M. Fertig } \\
\text { C. M. Schmidt }\end{array}$ & $\begin{array}{l}\text { Gerontocracy in Motion? European Cross- } \\
\text { Country Evidence on the Labor Market } \\
\text { Consequences of Population Ageing }\end{array}$ & 5 & $12 / 03$ \\
\hline 957 & $\begin{array}{l}\text { M. Ebell } \\
\text { C. Haefke }\end{array}$ & $\begin{array}{l}\text { Product Market Deregulation and Labor Market } \\
\text { Outcomes }\end{array}$ & 6 & $12 / 03$ \\
\hline 958 & $\begin{array}{l}\text { T. Brück } \\
\text { J. P. Haisken-DeNew } \\
\text { K. F. Zimmermann }\end{array}$ & $\begin{array}{l}\text { Creating Low Skilled Jobs by Subsidizing } \\
\text { Market-Contracted Household Work }\end{array}$ & 5 & $12 / 03$ \\
\hline 959 & $\begin{array}{l}\text { T. Bauer } \\
\text { H. Bonin } \\
\text { U. Sunde }\end{array}$ & $\begin{array}{l}\text { Real and Nominal Wage Rigidities and the Rate } \\
\text { of Inflation: Evidence from West German Micro } \\
\text { Data }\end{array}$ & 1 & $12 / 03$ \\
\hline 960 & $\begin{array}{l}\text { A. Constant } \\
\text { K. F. Zimmermann }\end{array}$ & $\begin{array}{l}\text { Circular Movements and Time Away from the } \\
\text { Host Country }\end{array}$ & 1 & $12 / 03$ \\
\hline 961 & $\begin{array}{l}\text { C. N. Teulings } \\
\text { C. G. de Vries }\end{array}$ & $\begin{array}{l}\text { Generational Accounting, Solidarity and Pension } \\
\text { Losses }\end{array}$ & 3 & $12 / 03$ \\
\hline 962 & $\begin{array}{l}\text { L. Goerke } \\
\text { M. Pannenberg }\end{array}$ & $\begin{array}{l}\text { Norm-Based Trade Union Membership: } \\
\text { Evidence for Germany }\end{array}$ & 3 & $12 / 03$ \\
\hline 963 & $\begin{array}{l}\text { L. Diaz-Serrano } \\
\text { J. Hartog } \\
\text { H. S. Nielsen }\end{array}$ & $\begin{array}{l}\text { Compensating Wage Differentials for } \\
\text { Schooling Risk in Denmark }\end{array}$ & 5 & $12 / 03$ \\
\hline 964 & $\begin{array}{l}\text { R. Schettkat } \\
\text { L. Yocarini }\end{array}$ & $\begin{array}{l}\text { The Shift to Services: } \\
\text { A Review of the Literature }\end{array}$ & 5 & $12 / 03$ \\
\hline
\end{tabular}

An updated list of IZA Discussion Papers is available on the center's homepage www.iza.org. 